\title{
GPR and aerial imageries to identify the recent historical course of the Obra River and spatial extent of Obrzańskie Lake, altered by hydro-technical works
}

\author{
Marcin Słowik
}

Received: 21 May 2011/Accepted: 29 December 2012/Published online: 10 January 2013

(C) The Author(s) 2013. This article is published with open access at Springerlink.com

\begin{abstract}
Ground penetrating radar (GPR) measurements have been conducted to retrace the natural course of the Obra River and changes of spatial extent of Obrzańskie Lake (western Poland). The Obra River valley was subjected to intensive anthropogenic transformation. Three artificial canals were constructed here in the beginning of the nineteenth century. The GPR surveys were done using a georadar MALA ProEx equipped with $250 \mathrm{MHz}$ antenna. The measurement was verified by coring and analyses of historical maps, aerial photographs, and satellite images. The research has shown that there are at least three elongated depressions preserved in the modern land surface near the village of Solec, situated in the middle course of the valley. Several structures suggesting functioning of a multi-channel pattern in the past have been detected inside and in the vicinity of the depressions. Filling the channels with silts and peats might have been the effect of flow deceleration caused by the construction of the Obra Canals. Moreover, situation of two of the retraced depressions suggests that the landforms might be the remains of a river bed disappearing in wetlands. Further studies including groundwater flux measurements in the area between the depressions are needed to confirm such hypothesis. Furthermore, the study allowed retracing the spatial extent of Obrzańskie Lake. The sediment structures detected by the GPR measurements and calibrated with coring were interpreted to be the traces of the lake shoreline. The interpretation was supported by the findings inferred from aerial and satellite images. It was shown that Obrzańskie
\end{abstract}

M. Słowik $(\bowtie)$

Department of Geographic and Geologic Sciences,

Adam Mickiewicz University, ul. Dzięgielowa 27,

61-680 Poznan, Poland

e-mail: slowikgeo@poczta.onet.pl; slowik@amu.edu.pl
Lake had had at least three islands and had been directly connected with a network of braided channels before the anthropogenic intervention. The spatial extent of the lake was significantly altered by the construction of the North Obra Canal. Disconnecting the lake from the Canal resulted in more than $50 \%$ decrease of the lake surface.

Keywords Ground penetrating radar - River bed pattern . Wetlands · Lakes · Human impact · The Obra River

\section{Introduction}

Many hydrological and geomorphological studies regard retracing changes of river bed patterns. Such reconstruction may be especially difficult in case of a river course subjected to hydro technical works. Ground penetrating radar (GPR) measurements are a very useful tool in such studies as they allow imaging the fragments of river beds and alluvial structures preserved in the shallow subsurface. The GPR method was applied in many studies concerning reconstruction of meandering (Leclerc and Hickin 1997; Vandenbenghe and van Overmeeren 1999; Huisink 2000; Gourry et al. 2003; Bersezio et al. 2007; Bowling et al. 2007; Kostic and Aigner 2007), braided (Bristow et al. 1999; Skelly et al. 2003; Lunt et al. 2004; Froese et al. 2005; Best et al. 2006; Bowling et al. 2007), wandering (Rice et al. 2009; Hickin et al. 2009) and transitional patterns (Vandenbenghe and van Overmeeren 1999; Bowling et al. 2007) in case of both sand and gravel bed river courses. Furthermore, a number of research works referred to the application of the GPR method to study the sediments' structures in wetlands, mires, and bogs. Jol and Smith (1995) reported that GPR surveys provide information concerning gyttja layers and other sediments under peats. Holden (2004) used 
the GPR method to detect soil pipes in a peat blanketed wetland to study hydrological connectivity between the pipes. Comas et al. (2005) analyzed stratigraphy of a domed bog using GPR surveys supported by coring. The measurements allowed determining the thickness of peat deposits filling the bog and detecting buried esker forms. Lowry et al. (2009) studied the mechanism of forming pools and streams in Allequash Wetland. They found GPR surveys useful to delineate peats/fine sands interface and identify a break in slope controlling groundwater flux. The surveys performed by Sass et al. (2010) allowed detecting the interfaces between peats, gyttjas, and underlying mineral deposits in alpine mires. The authors pointed that in some cases the GPR yielded more accurate depth assessment in comparison with probing using a metal rod. GómezOrtiz et al. (2010) have shown that despite unfavorable conditions such as high groundwater level and the presence of clay deposits attenuating the GPR signal, it was possible to detect clay layers in a wetland area. Pascucci et al. (2009) studied shores of glacial lake and discerned radar facies characterizing such factors as input of fluvial material to the shore of the lake, major storm events, transgressions, and regressions. Shuman et al. (2009) studied the changes of the Holocene lakes level in the Rocky Mountains and retraced its ancient shorelines using GPR surveys supported with core data. Kanbur et al. (2010) also have shown that GPR measurements are very useful in studying changes of spatial extent of lakes. The authors retraced the changes of the shoreline of the Egirdir Lake and indicated the existence of a pond in the vicinity of the lake in the last century (Kanbur et al. 2010). All the mentioned studies used the GPR method allowing a continuous illustration of sediment structures that is often beyond the reach of conventional methods (e.g. coring, trenching, information from outcrops or exposures). According to Lunt et al. (2004), the information derived from the conventional techniques is limited because it regards mostly the deposits situated above groundwater level. However, it should be noted that sedimentary information is essential to verify the GPR data (Ekes and Hickin 2001).

Many research works regarded the changes of river bed pattern which were triggered by an anthropogenic intervention. Bristow et al. (1999) and Skelly et al. (2003) studied the lower course of the Niobrara River where an intensive aggradation process occurred due to the construction of a water dam and the rise of the level base. An anthropogenic alteration of sediment structures was also presented by the GPR surveys conducted by Jol and Smith (1995) and Ekes and Hickin (2001). Babek et al. (2008) used GPR measurement to retrace a fragment of a meandering channel transformed into an artificial canal (the Morava River, the Czech Republik). Other examples are the transformations of the Obra River bed pattern (western
Poland; Słowik 2011a), the Quadalquivir River bed, and Doñana Wetlands (Alonso 2009). In such cases, remote sensing (satellite and aerial photographs) and geophysical (e.g. GPR) techniques supported with conventional methods may be useful to reconstruct the natural conditions of a river course or water reservoir. Such data play a key role in a restoration project.

The main goal of this paper is to retrace the natural course of the Obra River. During a field survey, elongated depressions were found in the modern land surface. The landforms were assumed to be the remains of river channels. Distinguishing river bed patterns active before the construction of the Obra Canals is especially important and interesting in case of this lowland river. Historical maps as well as research works of Słowik (2011a, b) indicate that various types of river bed patterns were functioning in the Obra valley in the eighteenth century (meandering, braided, and disappearing in wetlands). Results presented here may lead to identification of the factors that influenced the variability of river patterns in particular sections of the Obra valley. Is the river disappearing in wetlands a unique type of river pattern or is it only a "graphic interpretation" of water courses network proposed by the cartographers from the eighteenth century? Furthermore, situation and geology of the depression may influence groundwater flux and migration of contaminants in this area.

The paper reports the results of the field works including the GPR surveys and coring that to verify the data inferred from the archival materials. Moreover, aerial photographs and satellite images have been used to study the traces of the natural river bed pattern. Attention was also paid to the changes of a spatial extent of lakes in the Obra River valley. Choinski (1992) indicated that the surface of the lakes in the middle course of the Obra valley significantly decreased (from 10 to $50 \%$ of its original surface). Here, alteration of the spatial extent of the Obrzańskie Lake was studied as it may have resulted from hydro technical works. The paper presents the results in the form of $2 \mathrm{D}$ and $3 \mathrm{D}$ radar images, supported by core data and the analysis of aerial and satellite images.

\section{Study area}

The Obra River flows through the middle and western part of Poland (Fig. 1) and is the biggest water course between two other Polish rivers: the Warta and the Odra River. Its drainage area is approximately $4,000 \mathrm{~km}^{2}$. The river valley is located in the area shaped by the Vistulian glaciation 15,000-20,000 years ago.

The hydrological regime of the Obra River is influenced by the presence of lakes in its course which smooth the 


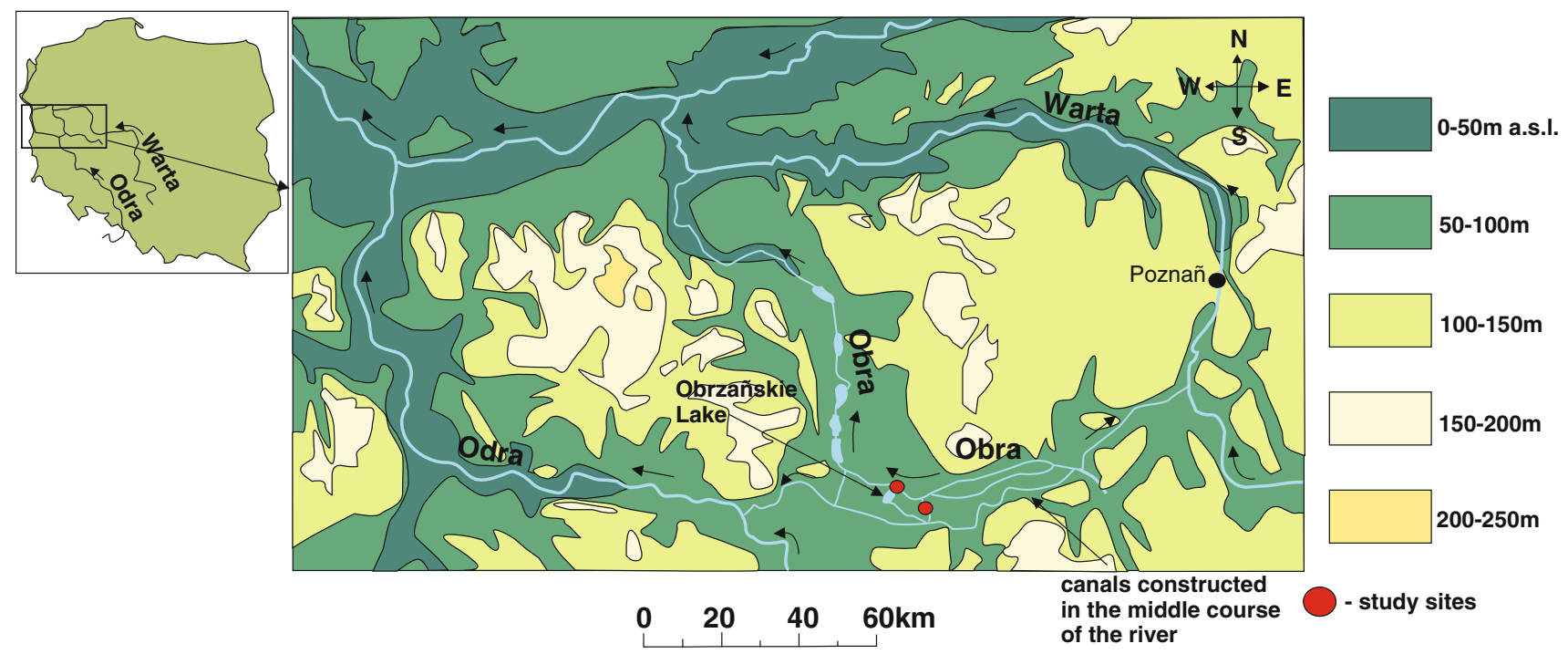

Fig. 1 The middle and the lower course of the Obra River (western Poland)

amplitude of water stages, discharges, and floods. According to Dynowska (1972), this water regime is counted among temperate regimes with spring floods and groundwater-rainfall water supply. Regularity of flood events in the lower course of the Obra River was observed by Słowik (2007) and Młynarczyk and Słowik (2008a, b). The middle course of the river is located within the Warsaw-Berlin proglacial stream valley. Alluvial silts, sands, gravels, peats, and muds are the main deposits covering the surface of the valley floor (Fig. 2). Glacial deposits are situated along the southern and northern side of the valley (Fig. 2; Mojski 1976). The surface of the valley is perpendicularly cut by an elongated depression with a small water course (the Dojca River; Fig. 2) and postglacial lakes: Wolsztyńskie, Berzyńskie, and Obrzańskie Lake. The depression is the remains of a subglacial tunnel (Bartkowski 1965) or, according to terminology used by Kehew and Kozlowski (2007), a tunnel channel. The two authors proposed five scenarios of forming tunnel channels taking into account such factors as readvance of lobes, formation of eskers within the channels and catastrophic subaerial melt-water flows (Kehew and Kozlowski 2007).

Originally, the Obra River valley was a large wetland (Hilczerówna 1967; Kurnatowski 1968) as highlighted by mud and silt deposits (Fig. 2). The historical maps from the eighteenth and the nineteenth century indicate a variety of river bed patterns in this area (meandering, braided, and disappearing in wetlands; Słowik 2009, 2011a). The map
Fig. 2 Surface sediments geologic map (Mojski 1976)

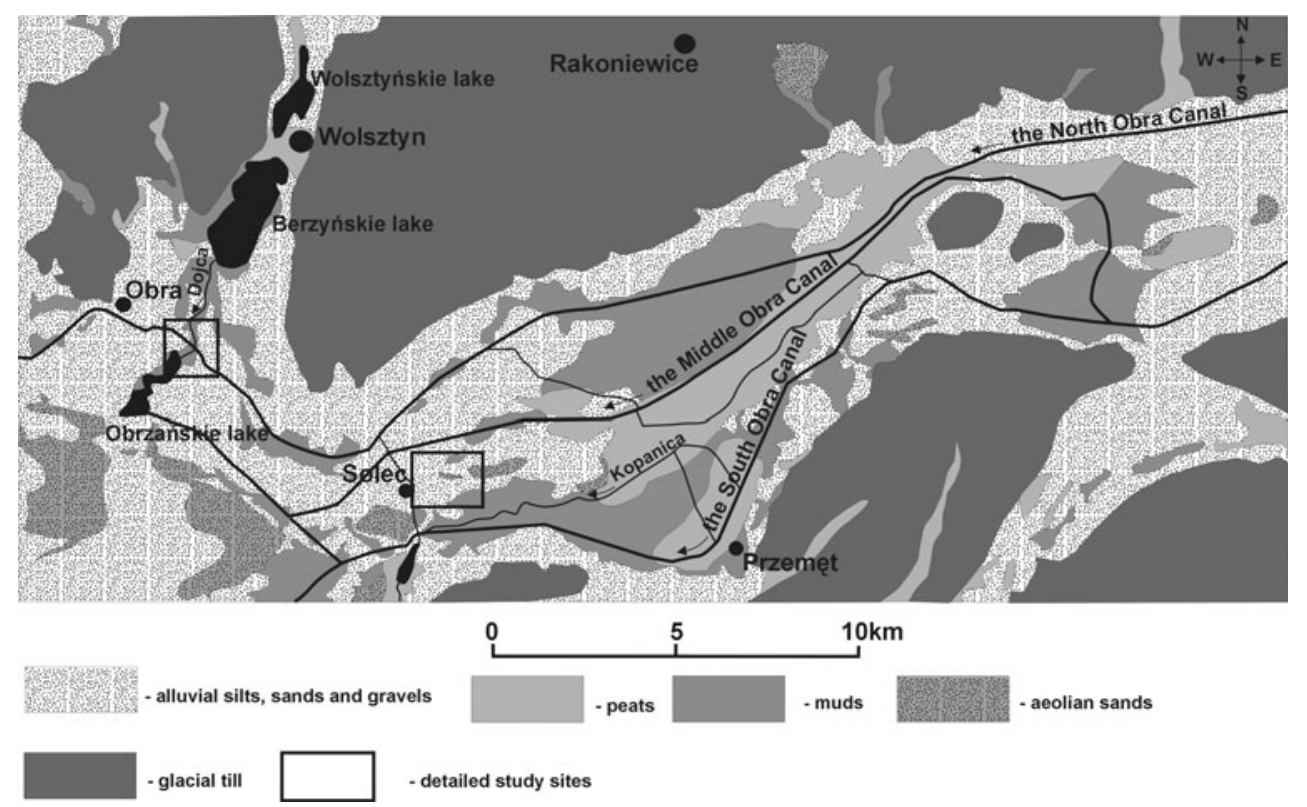



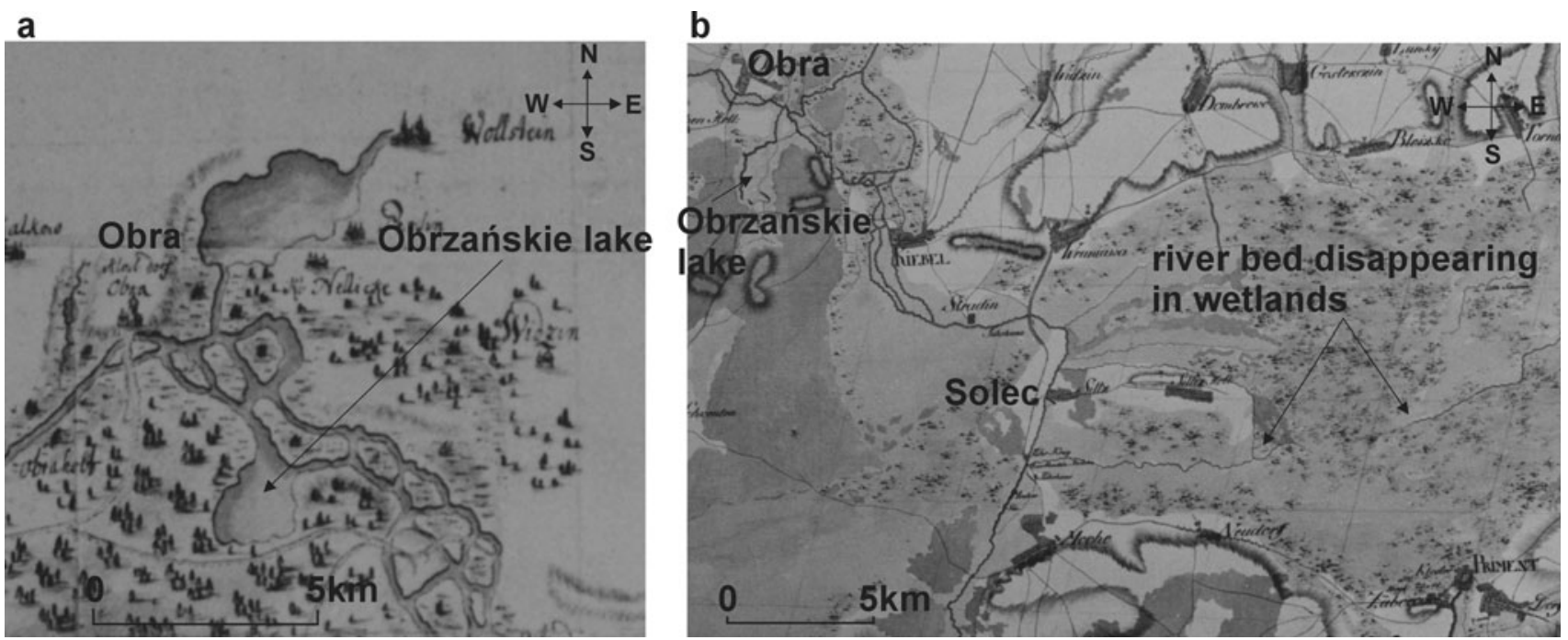

Fig. 3 Historical maps from 1735 (a) and 1793 (b) illustrating the Obra River pattern before the anthropogenic changes. The scale is approximate as distances are not maintained on the maps

from 1793 shows that the Obra River bed was disappearing in wetlands near the village of Solec (named as "Siltz" on the map) (Fig. 3). The maps from the nineteenth century show that there was no such type of the river bed at that time except for two elongated depressions near Solec (Figs. 4, 5). The situation of the depressions is different from the river bed disappearing in wetlands presented in the map from 1798. However, the older map has no scale and the distances between particular towns, villages or characteristic points of landscape are not consistent with modern mapping suggesting that these maps are not drawn to scale. The depressions were poorly marked on the maps from 1892 to 1893 partly due to covering the contour lines with the signatures marking forested areas (Fig. 5).

Furthermore, Obrzańskie Lake was connected with a network of braided channels near the village of Obra (named "Obra" or "Ober" on the archival materials from 1735 to 1793; Fig. 3). The Obra River bed was subjected to intensive anthropogenic transformations. Three artificial canals were constructed in its middle course in the nineteenth century (The North and South Obra Canals constructed in the years 1799-1806 followed by construction of the Middle Obra Canal in 1831). The main assumption of building the canals and a network of amelioration

a

b

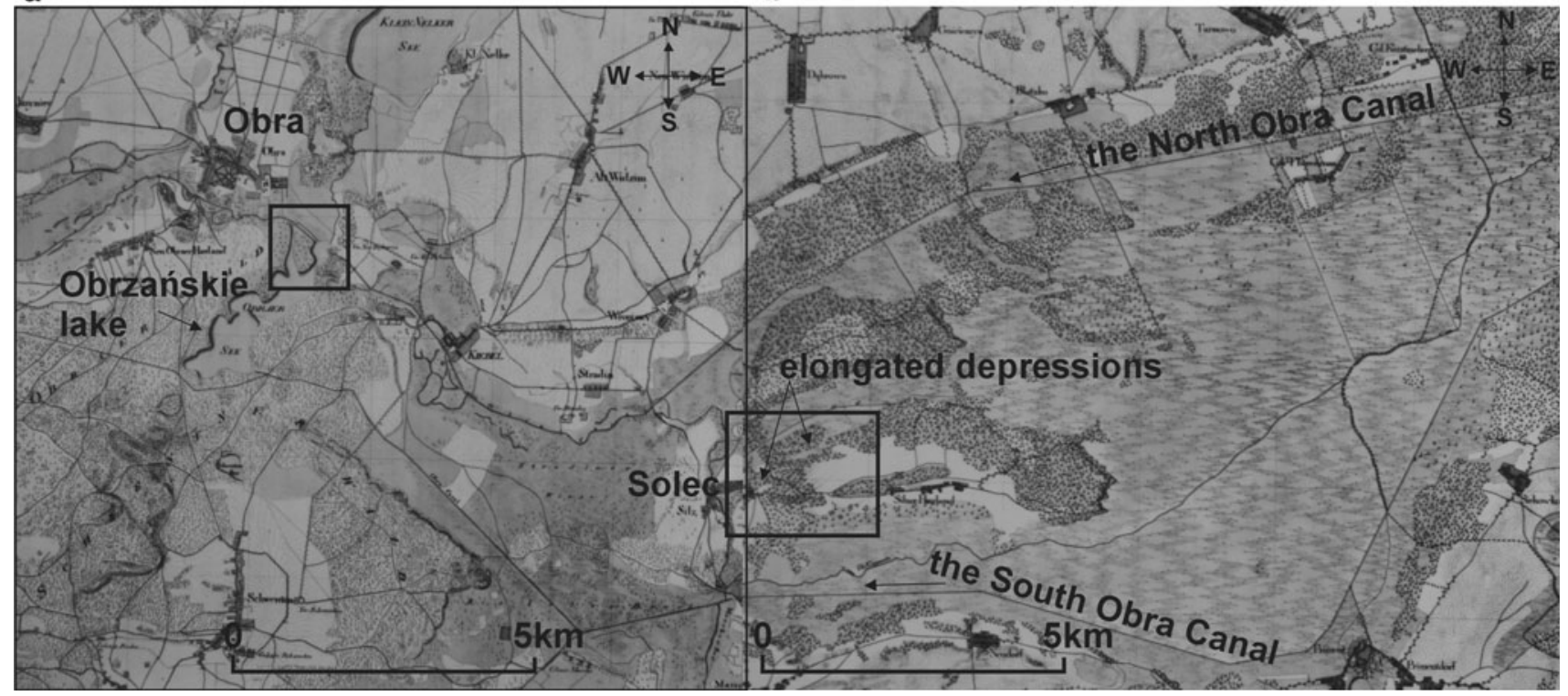

Fig. 4 Maps from 1826 (a) and 1828 (b) showing the artificial canals. Detailed study sites were marked with rectangles. Two maps illustrating the study sites were joined together here and in Fig. 5 
a

b

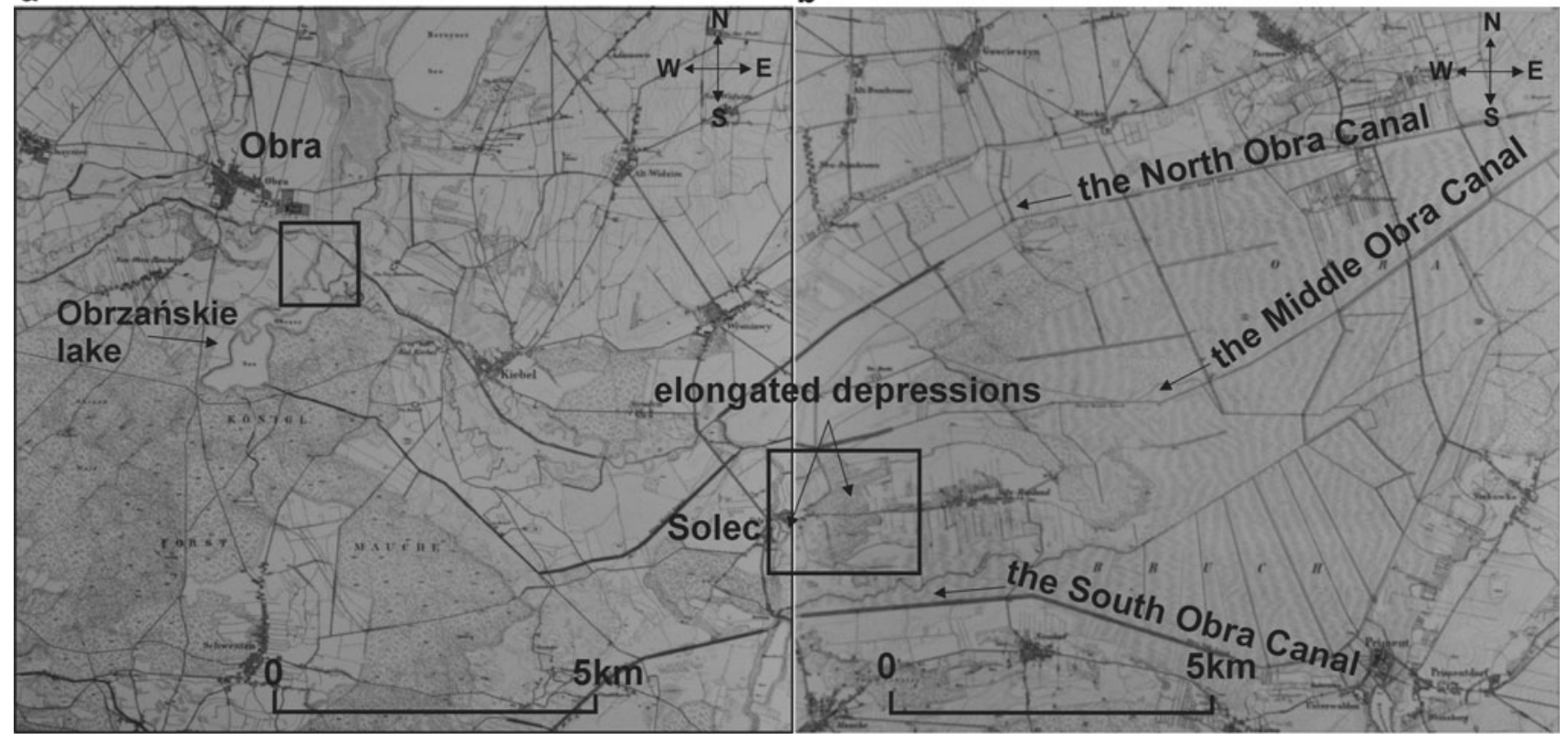

Fig. 5 Maps from 1892 (a) and 1893 (b). Obrzańskie Lake was disconnected from the North Obra Canal by that time. Explanations-see Fig. 4

ditches was lowering the groundwater level $30 \mathrm{~cm}$ below the land surface and turning the wetlands into an agricultural area (Schütze 1914). The maps from the nineteenth century indicate alteration of the spatial extent of Obrzańskie Lake (Figs. 4, 5). In 1828, the North Obra Canal flowed through the lake (Fig. 4). At the end of the nineteenth century, the lake and the Canal were connected by a small water course (1892; Fig. 5). Moreover, the Middle Obra Canal and a dense network of melioration ditches were constructed between 1828 and 1892. The Canal terminated in Obrzańskie Lake. Before that time, the lake had already been supplied by a water canal; however, it was a lateral connection between the lake and the South Obra Canal (the map from 1828; Fig. 4).

Detailed study sites are situated in the area where the network of the artificial canals is complex (Fig. 6a). The North and the Middle Obra Canal are interconnected by the Wroniawski Canal, the Connecting Canal and Obrzańskie Lake (Fig. 6a). The two Canals are connected with the South Obra Canal by the Kopanica River and the Wincentowski Canal (Fig. 6a). Furthermore, there is a number of canals and melioration ditches in this area. The detailed research areas have been chosen on the basis of the analysis of the historical maps. Study site I is located near the village of Solec (Fig. 6a, c). A field survey has shown that the elongated depressions, which might be the traces of the natural Obra River bed pattern, are situated in this area. The width of the landforms varies from 50 to $180 \mathrm{~m}$ (Fig. 6c). The depression near Solec is $500 \mathrm{~m}$ long. The other one, situated $1.5 \mathrm{~km} \mathrm{E}$ of the village (Fig. $6 \mathrm{c}$ ), is divided in two concave landforms. They were presented in Fig. 12c. The single depression was shown in Fig. 6c for clear presentation of the GPR sections. It has been chosen for detailed study due to a good access and fairly level ground suitable for the GPR surveys. The depressions are separated by several dunes (Figs. 2, 6c).

The second site is situated near the village of Obra (Fig. 6a, b) NE of Obrzańskie Lake within a depression. The surface of the lake is 82.5 ha and its maximum depth reaches $5.1 \mathrm{~m}$ (Choiński 1992). The landform is covered with wetlands and perpendicularly cut by the North Obra Canal (Fig. 6b). Its banks are secured by artificial dikes. The lake is connected with the North Obra Canal by a small water course (Fig. 6b). Moreover, there are several elongated depressions north of the Canal (Fig. 6b).

\section{Research methods}

\section{Ground penetrating radar}

The GPR method was applied to retrace the natural Obra River bed near Solec and changes of the spatial extent of Obrzańskie Lake. The GPR emits an electromagnetic wave. The signal is reflected at the interfaces of the deposits with different dielectric properties (Jol and Smith 1995; Neal 2004). Huggenberger et al. (1998) have shown that dielectric properties of sediments are strongly related to the changes in porosity and in the degree of water saturation within saturated and unsaturated zone, respectively. 


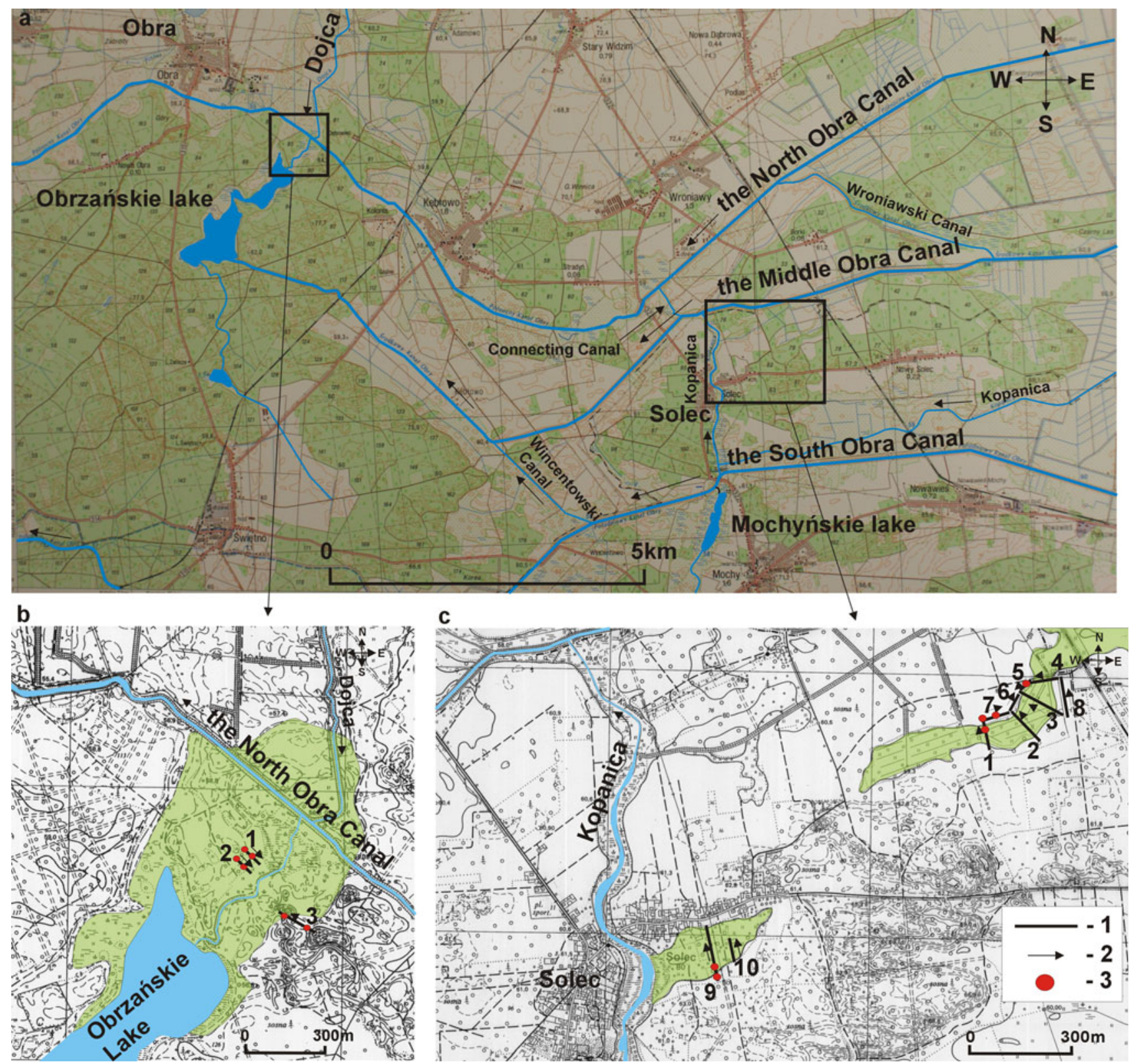

Fig. 6 Topographic maps illustrating situation of detailed study sites. 1 the GPR profiles, 2 directions of the GPR surveys, 3 core locations. The maps were obtained from the Cartographic Archive of

During field surveys, the GPR antennae (transmitter and receiver) are dragged along a profile line to obtain an image of a shallow subsurface. Differences in sediments' moisture, groundwater level, clay content, heavy minerals concentrations and diffractions caused by surface and subsurface objects influence both resolution and depth of measurement (Van Heteren et al. 1998; Bano et al. 2000; Neal 2004; Schrott and Sass 2008).

A MALA ProEx georadar equipped with a shielded $250 \mathrm{MHz}$ antenna was used in the presented research. The maximum depth range of the antenna may reach $8 \mathrm{~m}$ in optimal conditions (MALA 2008). However, due to high
Department of Geographic and Geologic Sciences (Adam Mickiewicz University, Poznań). Date of mapping: 1998. The studied depressions were marked with green in Fig. $6 \mathrm{~b}$ and c

groundwater level and the presence of silts and organic deposits, depths of penetration during the field surveys ranged from $1.4 \mathrm{~m}$ near Obrzańskie Lake to $3.1 \mathrm{~m}$ b.l.s. near Solec. The difference resulted from a relatively small electromagnetic wave velocity in organic deposits. Another factor limiting the depth penetration was high groundwater level near Obrzańskie Lake $(0.1 \mathrm{~m}$ below the land surface in elevated parts of the studied sections and equal to the land surface in lower parts). The antenna was moved manually during the field surveys. The measurement was triggered at constant spacings $(0.099 \mathrm{~m}$; Table 1$)$ by an odometer wheel. During the measurement in Solec, the radar pulse 
Table 1 Parameter settings during the GPR measurement in the study site near Solec

\begin{tabular}{ll}
\hline $250 \mathrm{MHz}$ antenna & \\
\hline Sampling frequency $(\mathrm{MHz})$ & 10,462 \\
Number of samples & 650 \\
Number of stacks & 8 \\
Time window (ns) & 62.1 \\
Trace interval (m) & 0.099 \\
\hline
\end{tabular}

wavelength amounted $0.28 \mathrm{~m}$. A GPR antenna resolution is one quarter of its wavelength (Bowling et al. 2007; Sass et al. 2010). Thus, the $250 \mathrm{MHz}$ antenna resolution was $0.07 \mathrm{~m}$. Near Obrzańskie Lake, the wavelength was $0.16 \mathrm{~m}$ which resulted in $0.04 \mathrm{~m}$ resolution. The value is close to the resolution of the measurement conducted in peat deposits by Sass et al. (2010) using a $200 \mathrm{MHz}$ antenna.

As no high resolution GPS was available during the field surveys, the GPR profile lines were situated along or parallel to the cart-roads that run through the study sites, or between characteristic points (e.g. single trees in meadows) that were possible to be identified in topographic maps and aerial images. When the profile line was situated parallel to e.g. a cart-road, the distance from the road to the line was determined using a measuring tape. It was possible then to mark the situation of the GPR profiles in the topographic maps (Fig. 6b, c) taking into account the position of the cart-roads and other characteristic points of the landscape.

The GPR surveys were conducted in August and September 2010. In study site I (Solec), the GPR measurement was conducted along 10 profile lines (Fig. 6c). Lines 1-4 were situated perpendicularly to the elongated depression $1.5 \mathrm{~km}$ E of Solec (Fig. 6c). Profile lines 5-8 were situated on both sides of the landform to investigate the structure of sediments in its marginal zone. Moreover, the GPR measurements were conducted along lines 9 and 10 perpendicularly to the depression near Solec (Fig. 6c). The length of Section 9 was only $85 \mathrm{~m}$ due to a fence limiting the access. The geophysical surveys were conducted using the following parameter settings (Table 1).

Six corings were done in Sections 1, 5, 7 and 9 (Fig. 6c) to recognize the composition and size of deposits and to determine the sediments' interfaces which are recorded as distinct reflectors in the GPR images. The type of deposits inside the depressions is different. In the depression $1.5 \mathrm{~km} \mathrm{E}$ of Solec (Fig. 6c), peat deposits were found in the surface layer. Fine sands, thin layers of coarse sands and silts were detected beneath the organic deposits. Peats underlain by sands occurred in the convex landform near the village (Section 9; Fig. 6c).

In study site II (Obrzańskie Lake), the GPR surveys were conducted along three profile lines in the marginal zone of a depression situated north of Obrzańskie Lake
(Fig. 6b). The site has unfavorable conditions for the surveys (high groundwater level, uneven ground level, dense vegetation). The area northward of Obrzańskie Lake is a wetland. For these reasons, the GPR measurement was done in the marginal zone of the wetland (Fig. 6b). Six corings were done in the study site. The parameter settings used during the GPR measurement were the same as near Solec (Table 1) except for the time window and number of samples. The thickness of the organic deposits does not exceed $2 \mathrm{~m}$ within the marginal zone of the depression. For that reason, the time window was shortened to $51.8 \mathrm{~ns}$. Using such settings, the depth of penetration was enough to reach the peats/fine sands interface in the GPR images.

All the GPR sections presented in this paper have vertical scales measured in nanoseconds (ns) two-way travel time. The GPR sections were calibrated with the core data which allowed determining the depth range of the measurements. The profiles with corings were treated as the reference sites (Figs. 7, 8, 9, 10,11). The calibration of particular sorts of the GPR reflectors with the core data was shown in Tables 2 and 3. A similar way to define the depth range of GPR surveys was presented by other authors (e.g. Skelly et al. 2003; Comas et al. 2005; Gómez-Ortiz et al. 2010).

The GPR images were processed using ReflexW 5.0 software. Subtract-mean (dewow) was applied to eliminate high frequency noise. Sedimentary structures commonly produce low amplitude reflections (Vandenbenghe and van Overmeeren 1999). AGC (Automatic Gain Control) gain and manual gain (y) tools allowed enhancing the low amplitude signals illustrating deposit's interfaces and structures. The background removal was used to show the near surface information covered by arrival of the direct waves (air wave and ground wave). Best et al. (2006) have shown that this tool allowed removing horizontal banding across the radar profile. Static correction was used for elevation corrections where necessary. Furthermore, the f-k migration procedure was applied. According to Vandenbenghe and van Overmeeren (1999), this is a useful tool that corrects dips of the GPR reflections and allows eliminating diffraction hyperbolae resulting from sediments' heterogeneity.

\section{Historical maps}

The maps from the eighteenth century (years 1735 and 1798) are the earliest materials illustrating the Obra (Fig. 3). However, the materials provide only general information how the Obra River bed looked like in the vicinity of a town or village. The maps have no scale and no maintained distances between characteristic points of landscape or towns. Moreover, the shoreline of Obrzańskie Lake was marked in a coarse way. Therefore, the exact marking of the detailed study sites on the maps was not possible. The maps from 1826, 1828, 1892 and 1893 


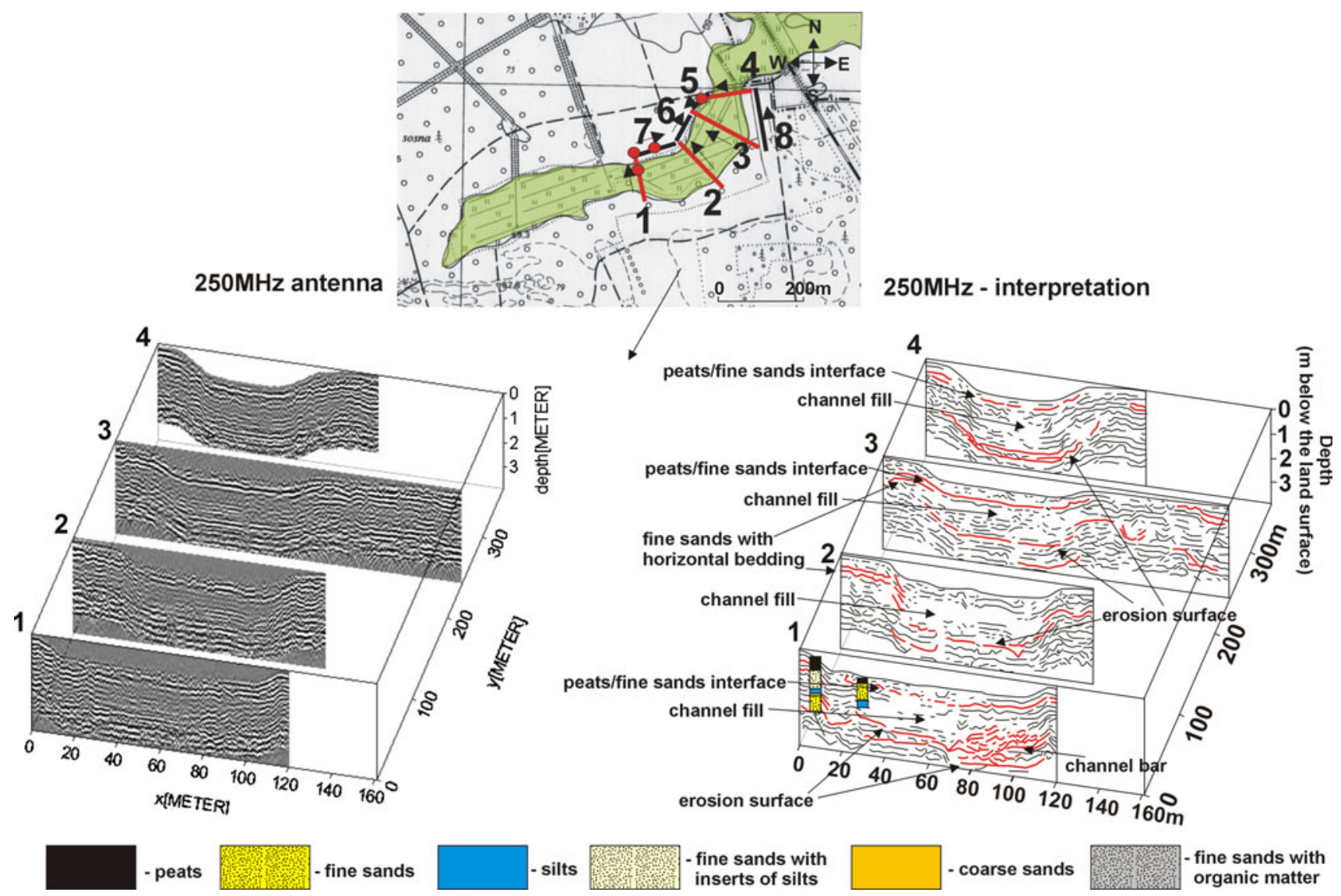

Fig. 7 3D diagrams of the GPR surveys conducted perpendicularly to the depression in the valley floor situated about $2 \mathrm{~km} \mathrm{E}$ of Solec and its interpretation. Sedimentary information was presented in core logs. 1,2, 3, 4-numbers of the GPR sections presented in the figure

(Figs. 4, 5) were edited in 1:25,000 scale. They were drawn by the General Staff of the Prussian Army. Triangulation measurement was the basis of its making. Thus, accuracy of distances, pattern of the river bed and shoreline of Obrzańskie Lake may be comparable with modern maps. It should be noted that the study site near Solec was placed at the border of the two neighboring maps. For that reason, the maps from 1826-1828 to 1892-1893 were joined into one for better presentation of the research areas (Figs. 4, 5).

The surface of the lake from the period preceding the hydro technical works has been calculated on the basis of its spatial extent delimited on the satellite and aerial image and the modern topographic maps. The scale of the maps was $1: 10,000$. The southern part of the lake was not presented in Figs. 6 and 13 due to a poor quality of the topographic map. The whole extent of the lake can be seen in the 1:50,000 map in Fig. 6 and in the satellite image in Fig. 13. The surface has been determined by placing a grid pattern over the lake maps and counting the squares (each of $2 \times 2 \mathrm{~mm}$ dimension). All the squares falling within retraced extent of the lake have been counted. At the line of the delimited extent, only those squares that were more than half inside the lake have been taken into account.
Aerial photographs and satellite images

Traces of the natural Obra River bed pattern and changes of the spatial extent of Obrzańskie Lake were analyzed using oblique aerial photographs. An aerial survey was conducted on the first of April 2010. At that time, the land surface was not covered with vegetation yet. This made possible to study the configuration of the Obra valley floor. Moreover, the survey was done during a period of high water stages. All the depressions in the valley floor were inundated and they were easy to discern. The height of the survey was from 100 to $300 \mathrm{~m}$. The approximate scale of the photos was $\sim 1: 10,000$. The oblique photographs were taken using a camera Sony $\alpha 350$. The angle of taking the photos was $\sim 10^{\circ}$ with horizon and $\sim 40^{\circ}$ without horizon. The resolution of the pictures was 14.2 megapixels. The oblique images were used to plan the geophysical surveys and provided information regarding the land cover which was useful in interpretation of satellite images.

Traces of the former channel pattern were also characterized using orthorectified Landsat ETM+ and Google Earth images. The Landsat dataset from the 13th June, 2000 (path 191, row 024) was downloaded from http://landsat.org 


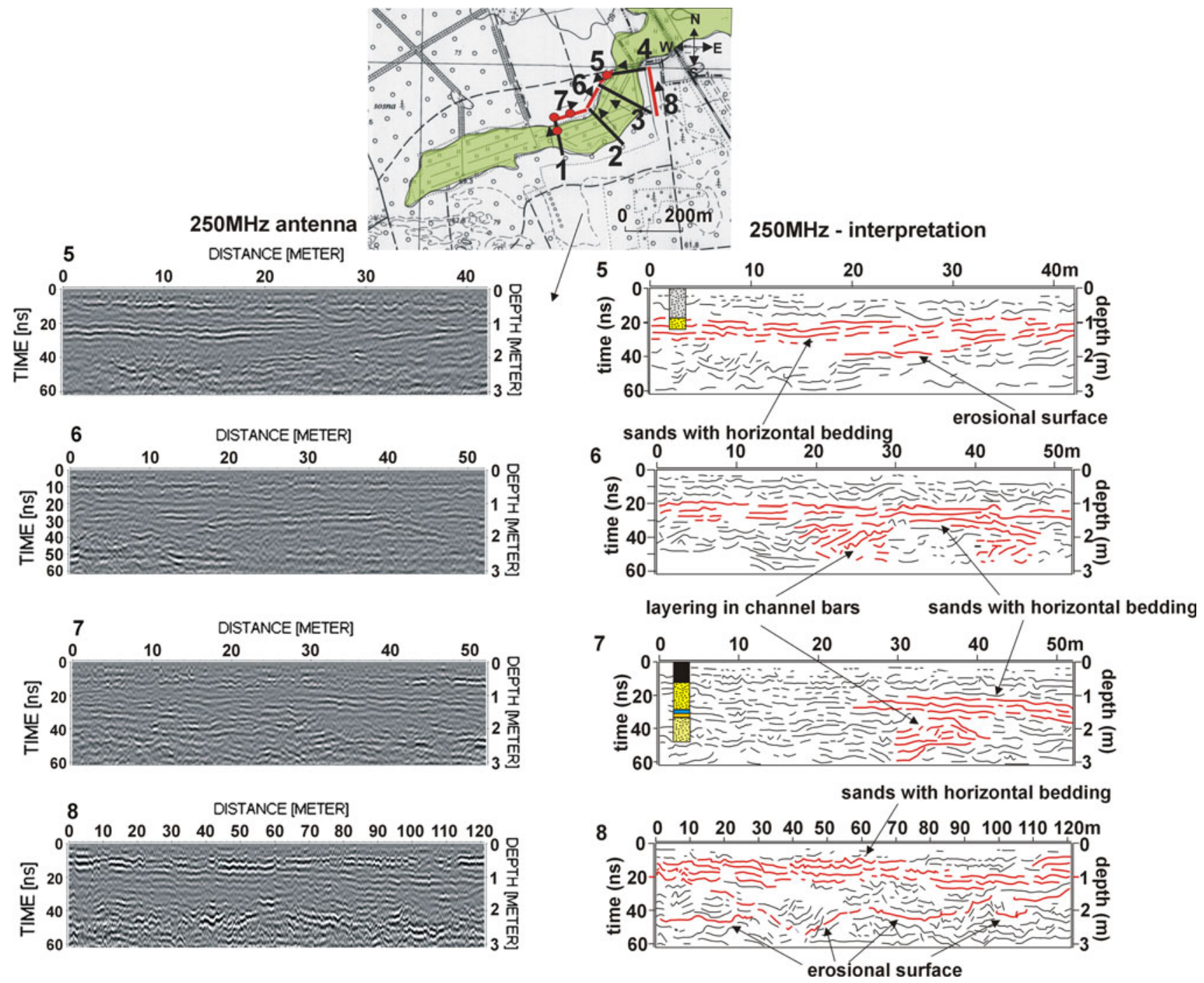

Fig. 8 Horizontal bedding, erosion surfaces and traces of channel bars in GPR Sections 5, 6, 7 and 8 situated along the depression. Numbers 5 , 6,7 and 8 in the figure are the numbers of the GPR sections. Explanation-see Fig. 7

website (Global Observatory for Ecosystem Services, Michigan State University). The images were processed in ArcGIS9.3.1 software. The best image for interpretation was produced by combining bands 5,4 , and 2 (Figs. 12, 13). The bands are usually applied to analyze vegetation moisture content (band 5), soil moisture monitoring and water body discrimination (band 4), and distinguish types of vegetation (band 2) (USGS 2012). The 5, 4, 2 composite was chosen because it highlighted areas of high soil and vegetation moisture content. Contrast stretching tool ("standard deviations" option) was applied to increase the visual contrast of the images. The "standard deviations option" was used to brighten raster datasets that normally appear dark. The resolution of the images was $30 \mathrm{~m}$.

During the analysis of the satellite images, the main attention was paid to distinguishing the elements featured with elongated and curved shape reminding river channels and situated close to the locations of river channels shown in the historical maps. The tone of colors was also important, especially in case of Obrzańskie Lake, to distinguish former shorelines. The findings inferred from the images were compared to the traces of channels that could be found in the aerial photographs and verified by field observations. The similarities that were noted in the satellite and aerial photographs were marked with arrows in Figs. 12 and 13. Moreover, a vertical aerial photograph of the area near Solec and satellite image showing Obrzańskie Lake were downloaded from http://maps.geoportal.gov.pl and $\mathrm{http} / / /$ maps.google.pl, respectively, to support the interpretation of the satellite images. The images have been presented in Figs. 12b and 13b. 


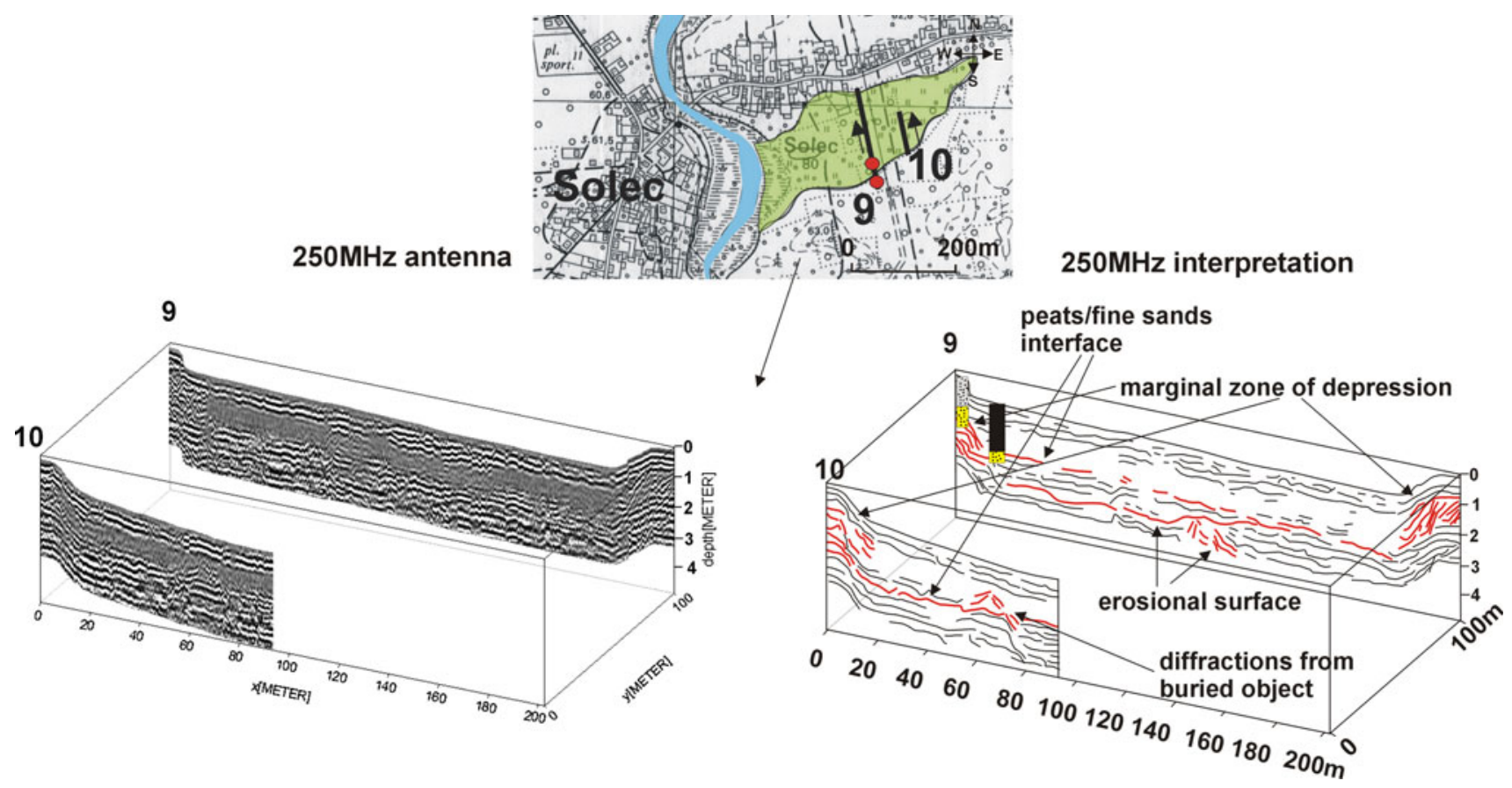

Fig. 9 3D diagrams presenting sediments structures in the depression situated near the village of Solec. Explanation-see Fig. 7
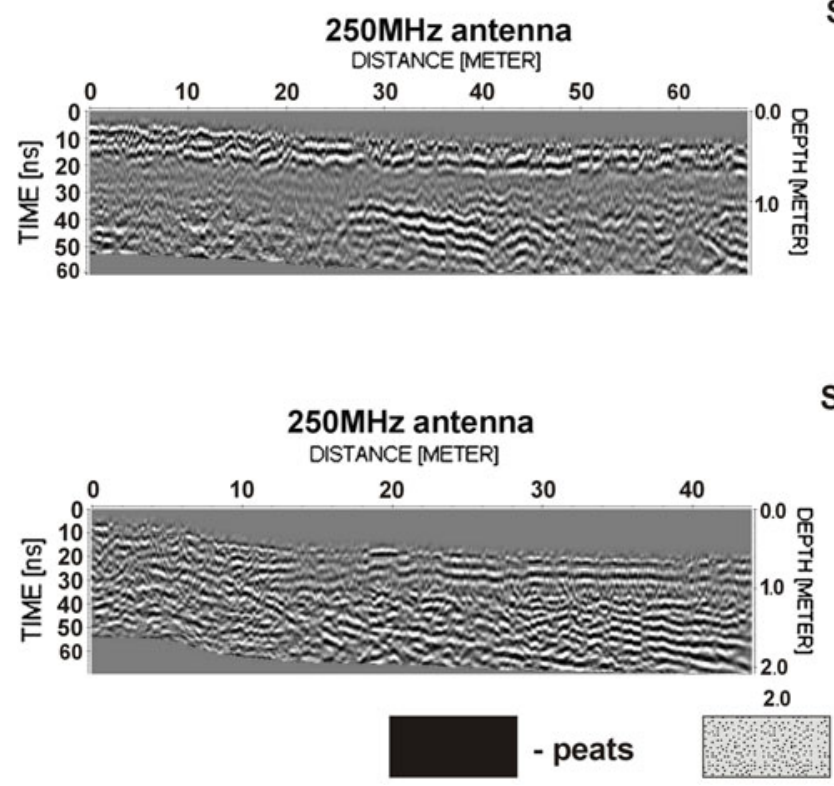

Section 1

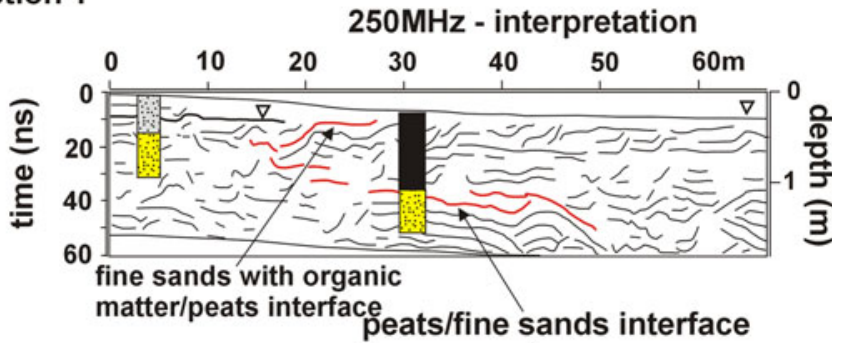

Section 2

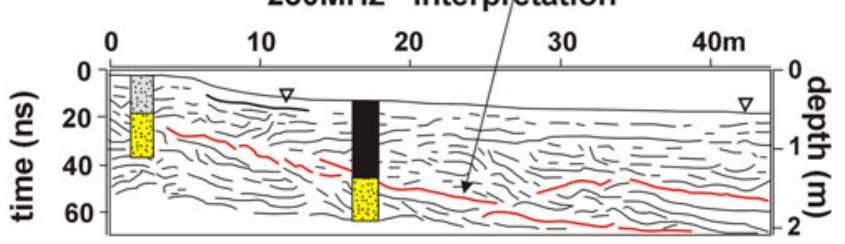

- fine sands with organic matter

- fine sands

Fig. 10 Peats/fine sands interfaces marking the marginal zone of Obrzańskie Lake. Situation of the GPR sections was marked in Fig. 6b

\section{Results}

Study site near Solec: types of GPR reflections and core data

The following GPR reflection patterns have been discerned in the GPR images (Figs. 7, 8, and 9): horizontal, dipping, curved, concave-up, wavy, faint or lack of reflections, and hyperbolic reflectors. Details referring to the connection between the reflectors in the GPR profiles and the core data, and interpretation, were shown in Table 2.

The occurrence of the curved, concave-up GPR reflectors delivered important information regarding formerly functioning river beds in the studied area. This type of the signal appeared in the sections situated perpendicularly to the studied depressions (Figs. 7, 9). The faint or lack of the GPR reflectors can be found above the concave-up pattern (Sections 1-4; Fig. 7, Section 8; Fig. 8 and Sections 9-10; 
Fig. 11 Marginal zone of Obrzańskie Lake marked with peats/fine sands interface in GPR Section 3. Situation of the section was shown in Fig. $6 \mathrm{~b}$
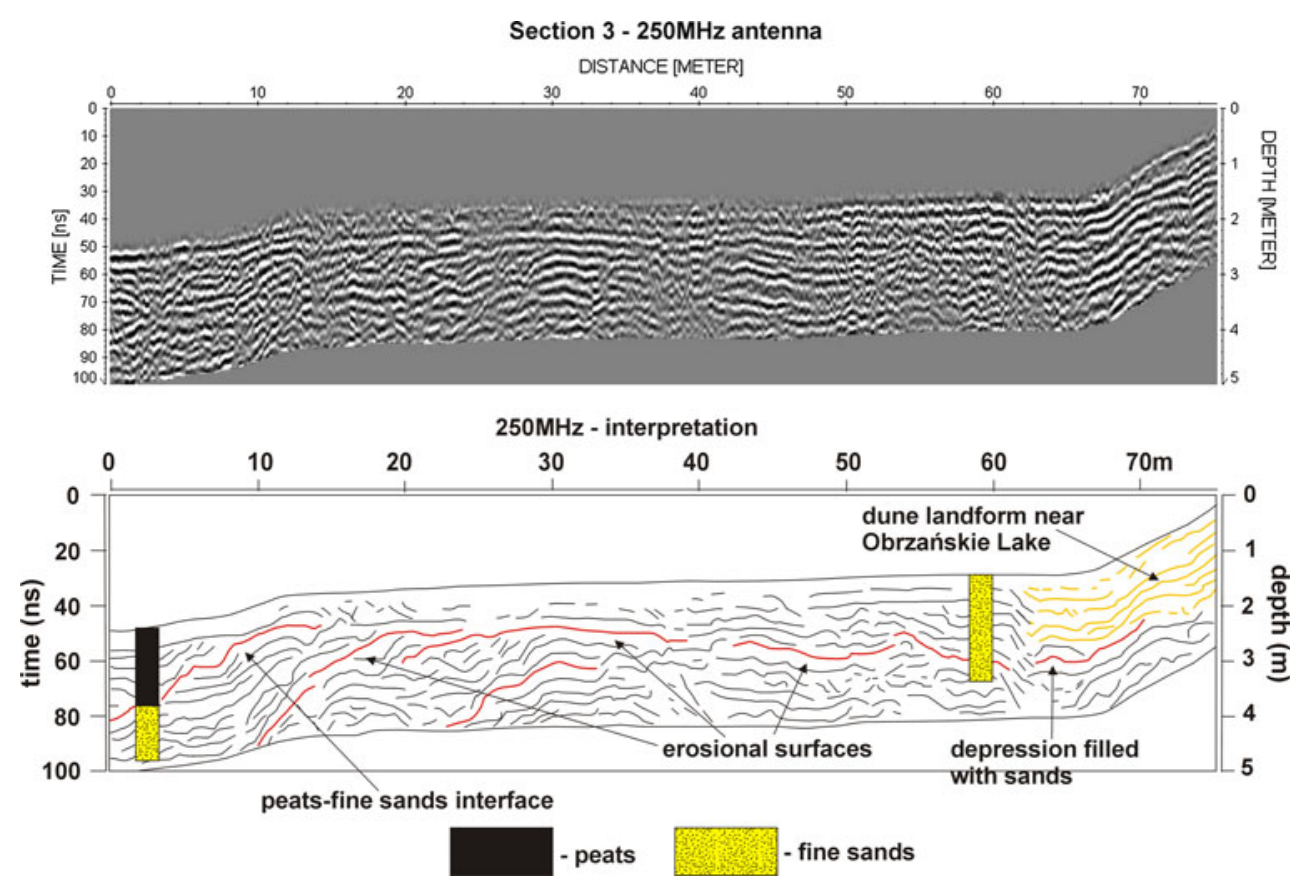

Table 2 Types of GPR reflections in the study site near Solec

\begin{tabular}{lll}
\hline $\begin{array}{l}\text { Type of GPR } \\
\text { reflections }\end{array}$ & Calibration with core data & Interpretation \\
\hline Horizontal & Fine sands (core logs in Section 5 and 7; Fig. 8) & Horizontal bedding in sand deposits \\
& $\begin{array}{l}\text { Peats (core log in Section 9; Fig. 9) } \\
\text { Channel fill }\end{array}$ & Layering within channel bars \\
$\begin{array}{l}\text { Dipping } \\
\text { Curved, concave-up }\end{array}$ & $\begin{array}{l}\text { Peats/fine sands interface (core log in Section 9; Fig. 9, and in Section 1; Fig. 7) } \\
\text { Eavy }\end{array}$ & Erosion surfaces \\
Faint or lack of & Fine sands (core log in Section 7; Fig. 8) & Elements of channel fill (small bed \\
reflections & Figs. 7 and 8) & forms) \\
& Peats (core log in Section 9; Fig. 9) & Bunnel fill \\
Hyperbolic & &
\end{tabular}

$b l s$ below the land surface

Fig. 9). Some of the wavy reflectors are also situated above the concave-up pattern (e.g. in Section 1 and 8; Figs. 7 and 8 , respectively). The dipping pattern can be noted between 10-20 $\mathrm{m}$ and 90-100 m of Sections 1-4 (Fig. 7), 30-40 m of Section 7 and $20-30 \mathrm{~m}$ and $40-50 \mathrm{~m}$ of Section 6 (Fig. 8). In the depression situated near Solec (Fig. 9), the reflectors can be seen between $0-20$ and 180-200 m of Section 9. The horizontal GPR reflections are situated in the top part of the profiles.

\section{Interpretation}

It marks the traces of erosion surfaces (Table 2) which suggests the presence of active river channels in the past. A similar GPR signals and interpretation were presented in many other studies (e.g. Leclerc and Hickin 1997;
Vandenbenghe and van Overmeeren 1999; Lunt et al. 2004; Rice et al. 2009). The width of the channels varies from $65 \mathrm{~m}$ (Section 1) to $90 \mathrm{~m}$ (Section 3; Fig. 7). In case of the depression near Solec (Fig. 9), one channel of $160 \mathrm{~m}$ width has been distinguished (Section 9; Fig. 9). Moreover, traces of erosion surfaces were found in Sections 5 and 8 (Fig. 8). Faint or lack of reflections are joined with channel fill deposits (peats and silts; Table 2). The thickness of the channel fills reaches $2 \mathrm{~m}$ in Sections $1-4$ (Fig. 7), $1 \mathrm{~m}$ in Section 8 (Fig. 8) and $2.5 \mathrm{~m}$ in Sections 9 and 10 (Fig. 9). Moreover, some of wavy reflectors are situated above the concave-up pattern and may be defined as elements of channel fill. Such case was noted by Skelly et al. (2003). It means that peats and silts may not be the only channel fill deposits. According to Skelly et al. (2003), wavy GPR reflections are the result of migration of small bed forms in 
Table 3 Types of GPR reflections in the study site near Obrzańskie Lake

\begin{tabular}{lll}
\hline $\begin{array}{l}\text { Type of GPR } \\
\text { reflections }\end{array}$ & Calibration with core data & Interpretation \\
\hline Dipping & $\begin{array}{l}\text { Fine sands with organic matter/peats interface (core logs in } \\
\text { Section 1; Fig. 10) } \\
\text { Peats/fine sands interface (core log in Section 3; Fig. 11) }\end{array}$ & $\begin{array}{c}\text { Marginal zone of reservoir filled with peat } \\
\text { deposits }\end{array}$ \\
& Fine sands (core log in Section 3; Fig. 11) & Erosional surfaces (lake-ward prograding beach \\
& Fine sands & face units) \\
& Ptructures within dune landform near Obrzañskie & Lake \\
Horizontal & Fine sands (core log in Section 3; Fig. 11) & Changes in decomposition of peat deposits \\
& Fine sands & Top segment of beach deposits \\
Curved, concave-up & Depression filled with sands \\
Wavy & Peats (core log in Section 1; Fig. 10) & Changes in decomposition of peat deposits \\
Faint or lack of & Fine sands (core logs in Sections 1-3 Figs. 10 and 11) & Lake-ward prograding beach face units \\
reflections & Fine sands (core log in Section 1; Fig. 10) & Admixtures of organic matter in sand deposits \\
& Peats (core log in Section 1; Fig. 10) & Reservoir filled with peats
\end{tabular}

Explanations-see Table 2
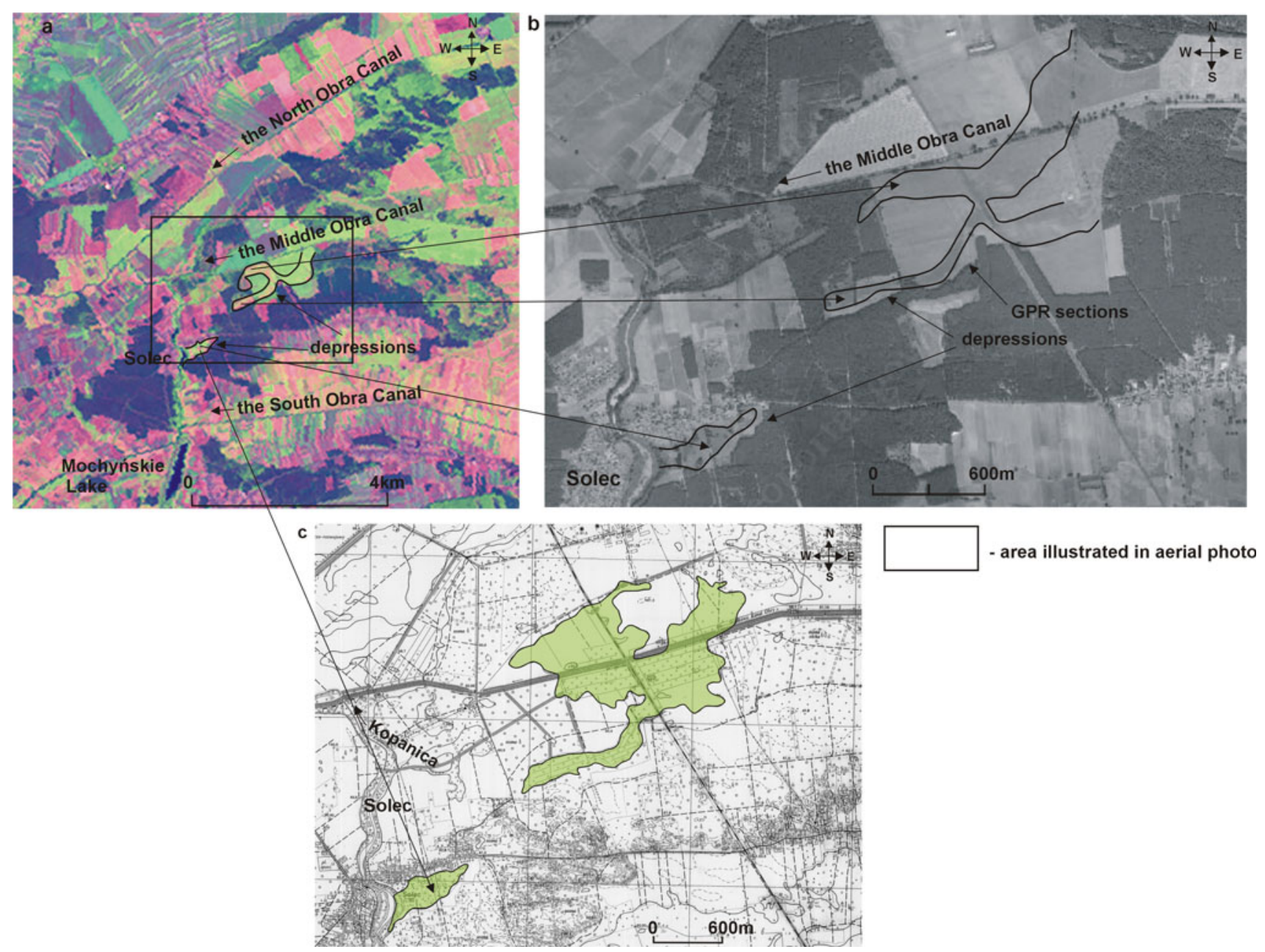

Fig. 12 LANDSAT ETM+ satellite image (a), aerial photograph (b) and topographic map (c) of the research area near Solec illustrating situation of the studied depressions. The image presented in Fig. 12b was downloaded from http://geoportal.gov.pl 

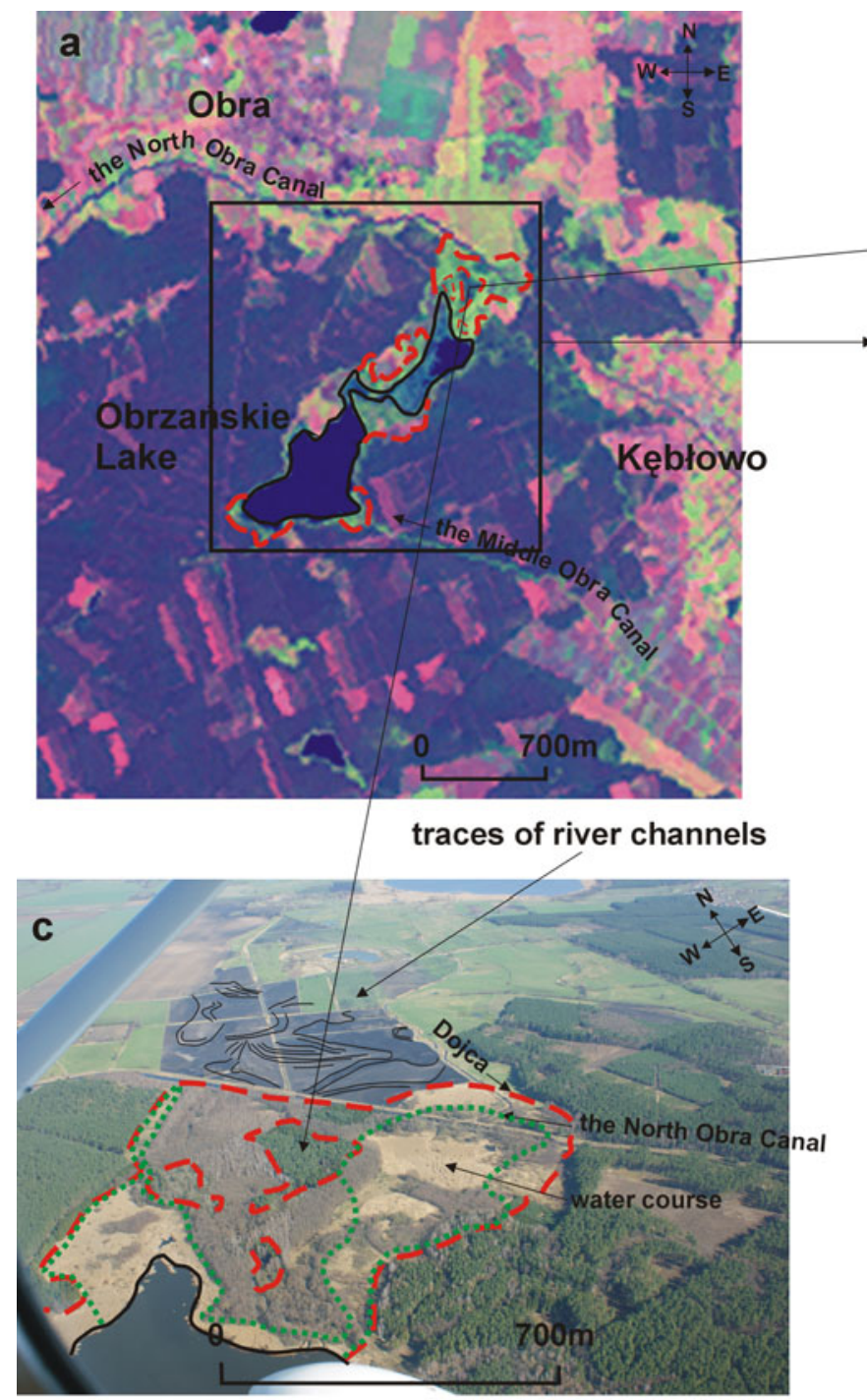

------ extent of the lake before construction of canals - extent of the lake in 1828

\section{- modern extent of the lake}

- the area presented in fig. $13 b$

Fig. 13 Changes of spatial extent of Obrzańskie Lake marked in LANDSAT ETM+ and CnesSpot satellite images (a and b, respectively), aerial photograph (c) and topographic map (d). The image in Fig. 13b was downloaded from http://maps.google.pl. There is

braided river deposits. Skelly et al. (2003) also reported that such type of reflections may define channel or scour pool fills and characterized the pattern as low-flow components.

The dipping GPR pattern marks layering within channel bars (Table 2). The sediment structures indicate migration of the channel bars in an active river bed. The horizontal reflections were interpreted as the traces of horizontal bedding
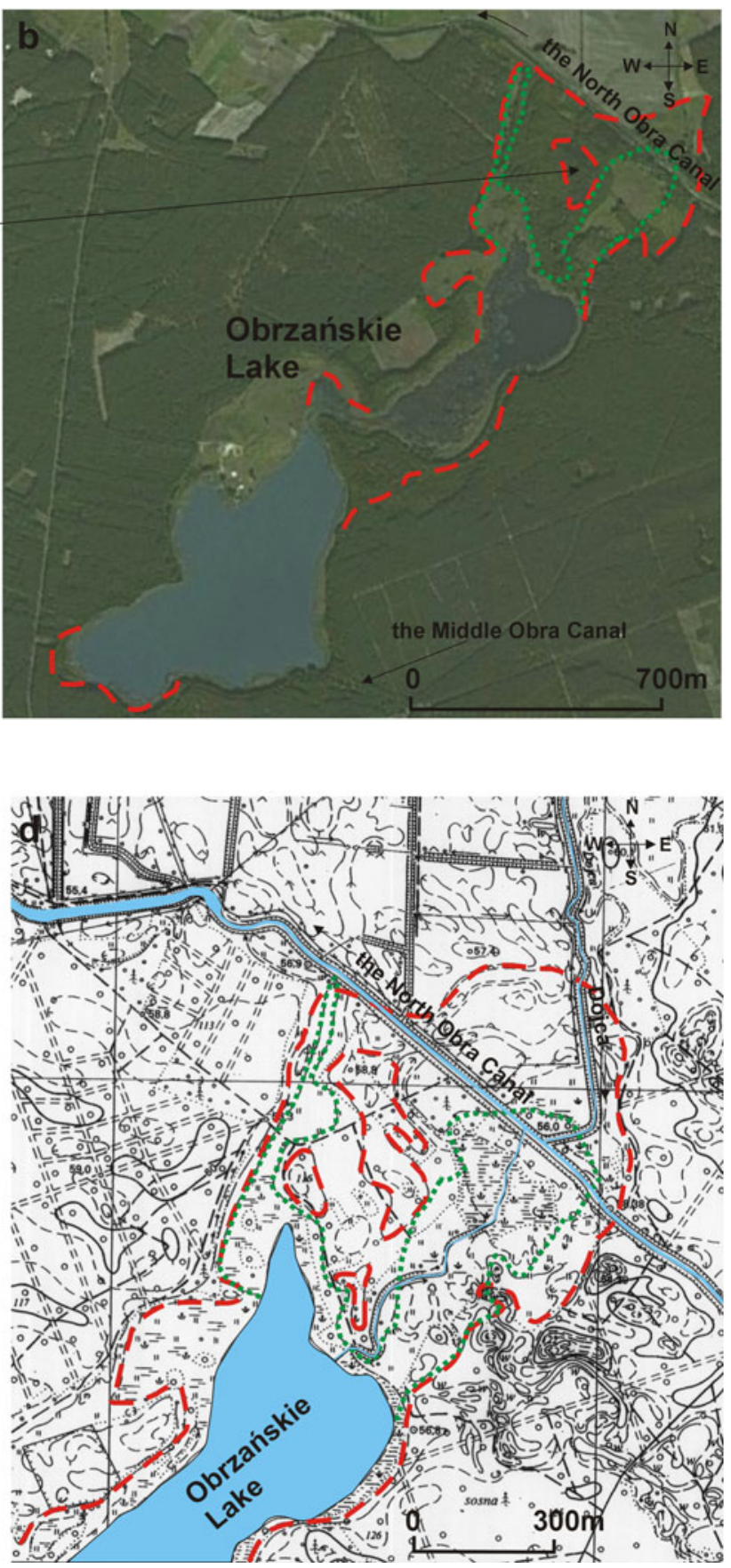

difference in the scale of the presented satellite images if the results are of relatively poor resolution of the LANDSAT image. Only the northern part of Obrzańskie Lake was presented in Fig. 13d due to a poor quality of cartographic materials

in fine sands (Figs. 7, 8). Many authors (e.g. Asprion and Aigner 1999; Huisink 2000; Ekes and Hickin 2001) interpreted such signal as vertically accreted bed-load sheets or stratified sheetflood deposits. The horizontal reflectors appearing in the top part of Section 9 (Fig. 9) may record growth layers or previous drying cycles of peat deposits. Such interpretation was presented by Jol and Smith (1995). 
Study site near Obrzańskie Lake: types of GPR reflections and core data

The GPR measurement conducted in the area near Obrzańskie Lake resulted in the GPR images showing various sorts of radar reflectors. The results of the surveys were presented in Table 3 for a concise presentation of types of the reflections in particular profiles as well as calibration of core data and interpretation.

The dipping GPR reflections can be seen between 15-50 m of Section 1, 4-35 m of Section 2 (Fig. 10) and 0-33 m of Section 3 (Fig. 11). Their occurrence is connected with peats and fine sands in Sections 1 and 3 (Table 3). The horizontal, wavy, and faint or lack of the GPR reflections also mark the mentioned deposits (Table 3). The particular connections between the mentioned reflectors and core data were shown in Table 3 and illustrated by the core logs in Figs. 10 and 11. The curved, concave-up signal, which is situated between 55 and $70 \mathrm{~m}$ of Section 3 (Fig. 11), appears within sand deposits.

\section{Interpretation}

In the presented GPR sections, dipping reflections mark a marginal zone of a reservoir filled with peat deposits underlain by fine sands (Figs. 10, 11; Table 3). Such pattern can also be noted in wetlands studied by Lowry et al. (2009), lateral parts of the alpine mires presented by Sass et al. (2010) and artificial reservoir described by Słowik (2011a). The dipping pattern distinguished in Section 3 (Fig. 11) is similar to GPR reflections presented by Pascucci et al. (2009). Together with the wavy pattern occurring in the profile, they were interpreted as wellbedded, lake-ward prograding beach face units with erosional surfaces (Table 3). A similar type of GPR reflectors was interpreted by Shuman et al. (2009) as an extent of a litoral zone during low stands of Hidden Lake.

In the top part of Section 1, the horizontal, wavy, and faint or lack of the GPR reflections may indicate changes in the peats decomposition (Table 3). Sass et al. (2010) suggested that undecomposed or very little decomposed peat can act as a reflector. Horizontal and wavy reflectors underlain by faint signal described peat deposits in the studies of Comas et al. (2004, 2005). Lowry et al. (2009) have shown that near the surface peat deposits were featured with strong reflections due to changes in organic content (e.g. wood, roots). The horizontal and concave-up reflectors distinguished in Section 3 mark a depression filled with sands (Fig. 11; Table 3). In the light of the conducted research, its origin cannot be defined and requires further studies regarding not only the lake but also neighboring dune forms. The faint or lack of reflections are also related to sands (Fig. 10; Table 3). The reason may be admixtures of organic matter found in the sediments. The study conducted by Gómez-Ortiz et al. (2010) has shown that sands may be illustrated by a faint GPR signal.

Remote sensing surveys: results

The analysis of the composite LANDSAT images and aerial photographs enabled to distinguish several types of the land cover such as e.g. forests, meadows, agricultural areas, urbanized areas and water bodies. However, the description of the results was limited here to the landscape features that are connected with the remains of formerly functioning Obra River channels. Elongated depressions were noted near Solec both in the satellite and aerial images (Fig. 12). The topographic map (Fig. 12c) shows that they are also indicated by the land surface configuration. In the satellite image (Fig. 12a), the depressions were marked with light green and light yellow. In the aerial photograph, they are underlined by relatively darker tones. In the case of Obrzańskie Lake, the depression situated $\mathrm{N}$ of the Lake was marked by various tones of green. Green dominates also along the shorelines. The area situated $\mathrm{N}$ of the North Obra Canal was marked with light green and light yellow which may be the effect of its agricultural use.

\section{Interpretation}

The dominating color of the depression situated near Solec is green as the spectral reflectance of vegetation is based on chlorophyll and water absorption in the leaf (USGS 2012). The aerial image (Fig. 12b) shows that meadows are a dominating element of the land cover in this area. Here, the differences in the soil moisture enabled to distinguish the depressions. Peat deposits form the top part of the depressions (Figs. 7, 8, 9). Possibly, the presence of the organic matter caused the decrease of the soil reflectance. The differences in the soil moisture also influenced relatively darker tones of the depressions with in the aerial image (Fig. 12b). In the study site near Obrzańskie Lake, the different tones of green characterizing the area $\mathrm{N}$ of the lake were influenced by types of vegetation and differences in the vegetation moisture (Fig. 13a). A comparison of the land cover (Fig. 13a-c) and the land surface configuration (topographic map; Fig. 13d) has shown that the pines grow on the elevated areas. Alders and reeds cover the remaining part of the depression marked with relatively lighter tones of green.

\section{Discussion}

Changes before construction of Obra Canals

The GPR measurements supported with coring allowed retracing elements of channels that had been active before 
the construction of the Obra Canals (Figs. 12, 14a1). Traces of at least two channels were found in Section 8 situated along the depression $1.5 \mathrm{~km} \mathrm{E}$ of Solec (Fig. 8). Discerned fragments of channel bars in the GPR sections indicate migration of bed forms. Similar structures were found by Kostic and Aigner (2007) in case of the Neckar River. The structures from Section 8 (Fig. 8) are similar to the prograding deposits of a sandy palaeochannel presented by Gourry et al. (2003). Lunt et al. (2004) studied channel bars in braided Sagavanirktok River where the river bed pattern was similar in many places to the discerned convergence of four depressions (Fig. 12b). It is possible that a multi-channel system was active here (Fig. 14a1). Such hypothesis is supported by the findings inferred from the satellite and aerial photograph (Fig. 12a, b) showing concave landforms converging NE of the studied area. They might be the traces of formerly functioning four channels (Fig. 14a1).

The historical maps show that Obrzańskie Lake was directly connected with a network of braided channels (Fig. 14a2). Their traces can be seen $\mathrm{N}$ of the depression in the aerial photograph (Fig. 13c). They may be the traces of the multi-channel network illustrated by the historical maps (Fig. 3). In the light of the conducted research, it is difficult to conclude whether the multi-channel patterns near Solec and Obrzańskie Lake were active at the same time. A determination of the age of deposits filling the channels is needed here to define the timing of the changes. Moreover, Obrzańskie Lake had at least three islands at that time (14a2). The presence of the islands was confirmed by distinguishing their shorelines in the GPR images (Figs. 10,11) as well as in the satellite and aerial images (Fig. 13). The islands, indicated by the dark green (Fig. 13a), are covered with pine forest (Fig. 13c). In satellite images, needles have darker response than leaves (USGS 2012). The shape of the retraced depression including the remains of the islands (Fig. 13a, b) is consistent with that presented in the aerial photograph (Fig. 13c) and the topographic map (Fig. 13d).

A significant change from wavy and dipping pattern to horizontal reflections was noted in GPR sections near Solec. Possibly, the floodplain deposits might have been eroded by an intensive sheetflood (Fig. 14b1). Homogeneous sands bodies were interpreted by Huisink (2000) as the effect of sheet-like deposition. Furthermore, such type of GPR pattern (continuous, low-angle clinoforms) was defined by Skelly et al. (2003) as high-flow components. The top part of the channel bars presented in Sections 6, 7, and 8 might have been eroded during such flood event. Such situation is similar to the sediment structures presented by Kostic et al. (2005) in fluvioglacial deposits and Kostic and Aigner (2007) in alluvial deposits. However, Kostic and Aigner (2007) described a transformation from braided to meandering pattern. In the presented case, a transition from the multi-channel to single planform is possible (Fig. 14b1) due to the lack of palaeomeanders in the studied area (Fig. 12). It was noted that the horizontal signal appears only in the lateral parts of the GPR sections oriented across the depression (Fig. 7). It may be suggested then that the horizontal bedding structures were eroded by a single channel. Such possibility is supported by the map from 1793 indicating that the studied depressions might have been used at that time by small, sinuous or meandering tributaries of the Kopanica River (Fig. 3). The intensive flood event might also have formed the prograding beach deposits found near Obrzańskie Lake (GPR Section 3; Fig. 11; see also Fig. 14b2). Pascucci et al. (2009) proposed that such deposits were the result of by major storms and/or large floods. As the lake was connected with the braided channels (Fig. 14b2), flood events might have had an influence on the fluctuations of water level in the lake.

The map also shows that a river bed disappearing in wetland was functioning near Solec (Figs. 3, 14a1, b1). On the basis of the conducted research, such phenomenon cannot be confirmed. Lowry et al. (2009) reported that springs in wetlands may discharge from preferential flow paths formed by soil pipes in peat deposits. In the studied case, the retraced depressions are intersected by a set of convex landforms, possibly dunes (Figs. 2, 12c). The situation and geometry of the studied depressions may suggest the presence of such river pattern in the past, however, further research including groundwater flux measurement in the area between the landforms is needed here.

In the light of the presented research, it is difficult to define the timing of the changes that took place before the hydrotechnical works. Further research, including sediment dating, is needed here to establish a refined timescale, which without determined age of the deposits stretches from the period of deglaciation to the end of the eighteenth century.

\section{Changes after construction of Obra Canals}

Silts and peats in the top part of the studied depressions point to flow deceleration and transition from the fluvial to a low-energetic, stagnant water environment (Fig. 14c1, d1). According to Bridge (1993 in: Lunt et al. 2004), channel filling is the result of reducing discharge, flow diversion and/or accumulation of sediment in the channel entrance. In the presented study, accumulation of organic deposits was conditioned by elongated depressions formed in fluvial environment. The alteration might have been caused by the construction of the Obra Canals; one of the main objectives of the works was lowering the groundwater level (Schütze 1914). The maps from 1826 to 1893 show 
Fig. 14 Changes of the Obra river pattern and spatial extent of Obrzańskie Lake. The study sites show separate maps as there is no evidence (e.g. dating of sediments) for their simultaneous evolution before the construction works. The maps show the salient features regarding the network of water bodies in both studied areas. Near Obrzańskie Lake, the braided pattern was redrawn from the historical map from 1735 (Fig. 3). The changes of the lake surface were inferred from its retraced extents, shown in Fig. 13. The scale of the presented schematic maps is general due to low accuracy of the materials from the eighteenth century

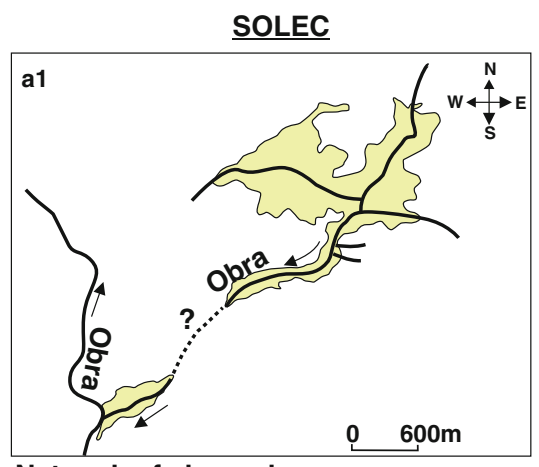

Network of channels

INTENSIVE network of channels

The lake (with islands) connected to network of channels

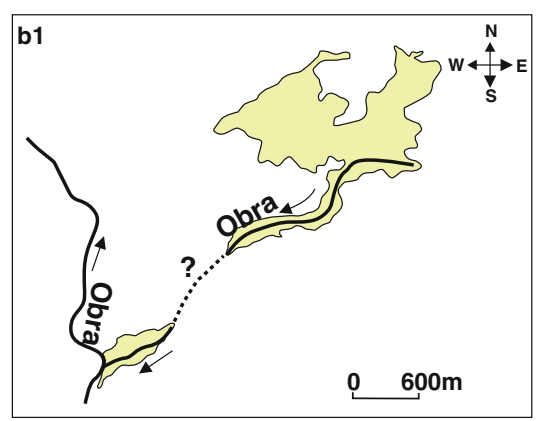

Transition to single channel pattern

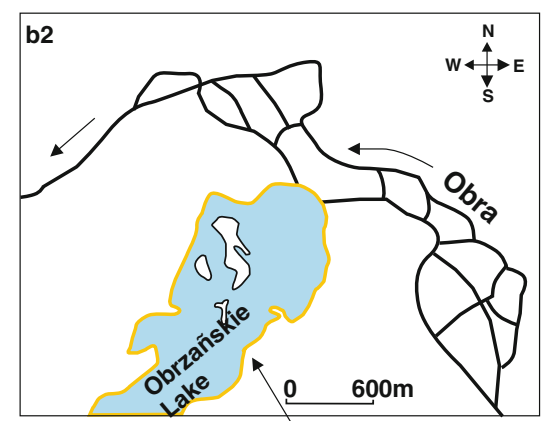

Forming prograding beach face units within shores of the lake

CONSTRUCTION OF OBRA CANALS (1799-1806)

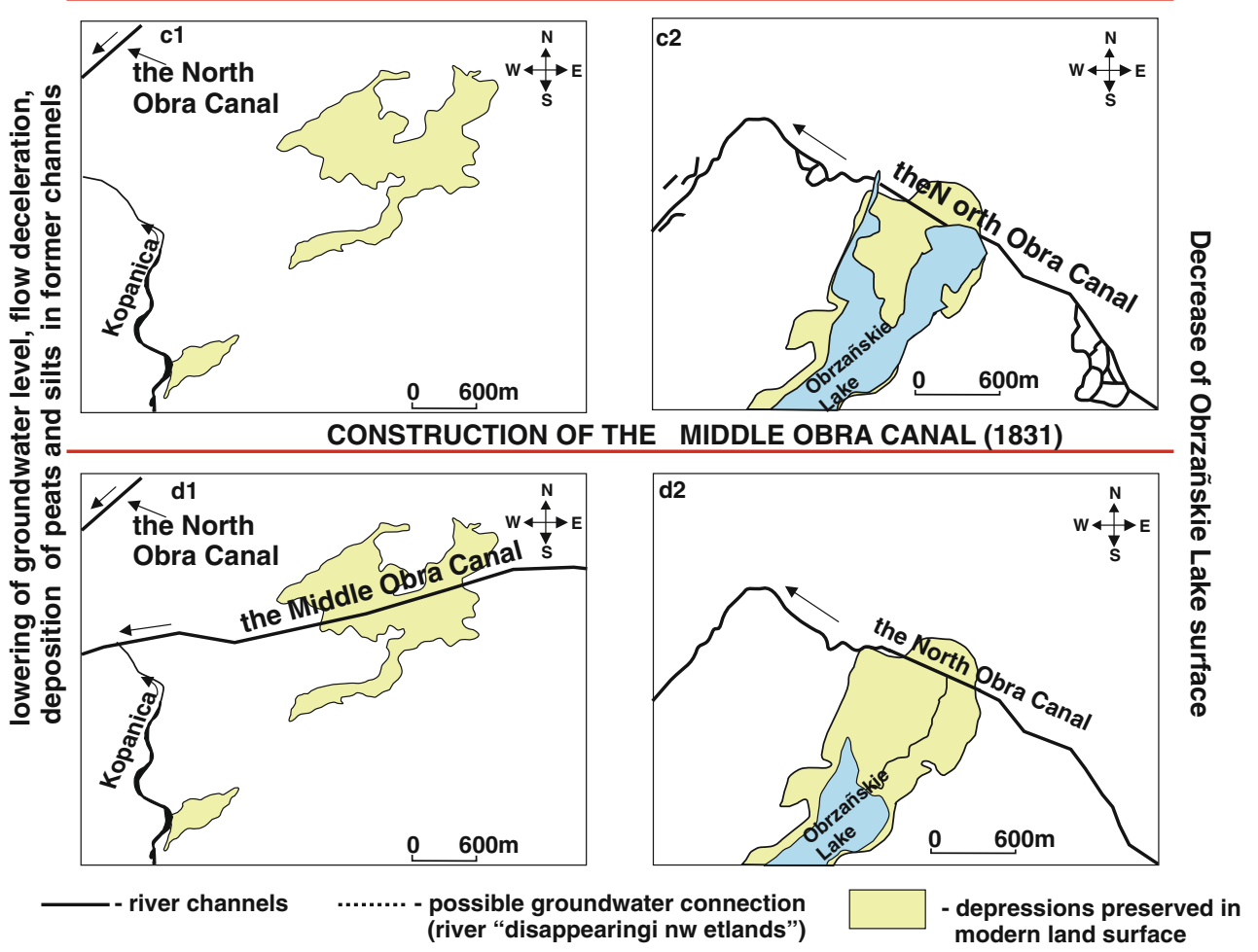

that there was no active river bed in the depressions at that time (Figs. 4, 5).

The hydro technical works have also influenced changes of the spatial extent of Obrzańskie Lake (Fig. 14c2, d2).
In 1828, the lake was connected with the North Obra Canal by two long bays (Figs. 4, 14c2). The lake level may have decreased between the second half of the eighteenth century and 1828 due to the construction of the canals. Traces 
of the extent of the lake in 1828 were preserved in the modern land surface (Fig. 13). They are situated in the area which is now the lowest part of the depression $\mathrm{N}$ of the modern lake (Fig. 13c, d). The retraced extent of the lake (Figs. 13, 14c2) is similar to its shape in the map from 1828 (Fig. 4). Lake surface transformations were also presented by Kanbur et al. (2010). They have shown that an island situated in Egradir Lake became part of the lake shore due to anthropogenic intervention (Kanbur et al. 2010). Further decrease of Obrzańskie Lake surface can be noted between 1828 and 1893 (Fig. 14d2); it may have been caused by cutting off the lake from the North Obra Canal. The depressions near Solec were cut by the Middle Obra Canal built in 1831 (Fig. 14d1). The construction did not result in any permanent change e.g. in the shape of the depressions, however, it might have had an important impact on groundwater flux in the studied area. The magnitude and nature of this influence may be the matter of future studies in this region.

Retracing the former extents of the lake allowed calculating its surface from the period preceding the construction of the Obra Canals. The modern surface of Obrzańskie Lake is 82.5 ha (Choiński 1992). It had amounted 181 ha before the construction of the Canals which means that the modern extent is more than $50 \%$ smaller. A decrease of a lake extent due to artificial constructions was also presented by Kanbur et al. (2010). The land reclamation may have had an important influence on the observed decrease. The influence of land use changes on the surface of Dongting Lake was described by Du et al. (2011). The authors reported that land reclamation resulted in increased sedimentation and decreased water storage (Du et al. 2011). Waters et al. (2009) also concluded that hydro technical works and agricultural land use resulted in decreasing of an extent of Mattamuskeet Lake.

The presented results, regarding both detailed study sites, may be useful in a project which would aim to restore the natural river bed pattern within chosen sections of the Obra River valley. Such restoration would influence the natural values of the area and may be an important impulse for e.g. development of tourism.

\section{Geophysical and remote sensing surveys}

as complementary methods

The presented study shows that geophysical and remote sensing methods can be applied to retrace fragments of channels that had been active before the construction works. Using a similar approach, it was possible to distinguish the former spatial extent of Obrzańskie Lake. The GPR surveys and the analysis of the satellite and aerial images were treated here as complementary research methods. The studies of Blumberg et al. (2004) and Lunt et al. (2004) are the examples of combining the two approaches. The satellite and aerial surveys enabled to distinguish the former extent of Obrzańskie Lake as well as the islands that had been present there before the hydro technical works. They are marked in the modern land surface by different types of the vegetation covering the area (Fig. 13). The aerial photograph presented in (Fig. 13c) was taken in April just before the vegetation season when the differences were easy to be observed. Such delimitation would be impossible using only the geophysical measurement; the GPR sections indicated only the near shore zone of Obrzańskie Lake and do not indicate whether it belongs to an island or lake shore. Furthermore, it was possible to mark the extent of the lake from 1828 in the aerial photographs (Fig. 13b, c) on the basis of the land cover variability. In the area near Solec, the satellite images enabled to mark the shape of the elongated depressions preserved in the modern land surface (Fig. 12a). Here, the differences in the soil moisture enabled to distinguish the depressions.

However, it should be noted the remote sensing surveys do not provide all needed data when retracing river channels. The study of Słowik (2011b) showed that some of the palaeochannels in the lower course of the Obra River could not be distinguished using remote sensing data due to a sand layer covering the alluvial structures. GPR surveys enabled in such case to distinguish a network of braided channels that were active in this area in the past (Słowik 2011b). Moreover, the geophysical technique provides information about fluvial sedimentary structures of the shallow subsurface (e.g. channel bars, chute channels, horizontal bedding, erosional surfaces). When GPR sections are calibrated with core data, events influencing changes of a river pattern can be distinguished. This is the case of the presented study sites where it was possible to distinguish an intensive flood event resulting in formation of the erosional surface and horizontal bedding structures near Solec and lake-ward prograding beach face units within the shores of Obrzańskie Lake.

\section{Conclusions}

The GPR measurement supported with coring and the analysis of satellite images, aerial photographs, historical cartographic materials and the modern topographic maps allowed retracing the natural course of the Obra River bed and changes of the spatial extent of Obrzańskie Lake. The study allowed distinguishing the following phases of evolution:

1. A multi-channel pattern was active in the study sites in the past. Obrzańskie Lake had at least three islands at that time and was directly connected to the network of channels. 
2. Occurrence of an intensive flood event which might have caused a transition from the multi-channel to single pattern near Solec and have influenced forming of sedimentary structures (prograding beach deposits with erosional surfaces) within the shores of Obrzańskie Lake.

3. The construction of the Obra Canals (years 1799-1806) may have caused lowering the groundwater level in the studied areas. As a result, the channels near Solec stopped functioning and were filled with peat and silt deposits. In 1828, Obrzańskie Lake was connected with the North Obra Canal by two long bays.

4. Before 1893, the lake had been separated from the Canal. The construction of the Obra Canals may have resulted in decreasing of the lake surface. The modern surface of Obrzańskie Lake is more than $50 \%$ smaller than before the hydro technical works.

It should be noted that the presented study does not answer all questions regarding changes of the Obra River pattern. Data regarding the age of the alluvial deposits is needed to determine whether the distinguished phases of evolution were simultaneous in both studied areas. The analysis of a higher resolution satellite or LIDAR images is also required to study the evolution of the valley in a more detailed way. Furthermore, no direct evidence for functioning of the river bed disappearing in wetlands in the studied area has been found. The archival materials show that such river bed pattern had been present in the vicinity of Solec before the anthropogenic transformations. Further research regarding groundwater connections between the studied depression is needed.

Acknowledgments The results presented in this paper are part of a research program "Determining changes of river bed pattern in the middle course of the Obra Valley using analysis of satellite and aerial images, and GPR (ground penetrating radar) method" supported by the National Science Centre Grant no 2011/01/B/ST10/04930. Special thanks to MSc Remigiusz Tritt for his great help during field surveys. Comments from three anonymous reviewers significantly improved quality of the paper.

Open Access This article is distributed under the terms of the Creative Commons Attribution License which permits any use, distribution, and reproduction in any medium, provided the original author(s) and the source are credited.

\section{References}

Alonso CU (2009) Wetland management at Doñana natural space (DNS). Internal report of Conservation Department - Doñana Natural Space

Asprion U, Aigner T (1999) Towards realistic aquifer models: threedimensional georadar surveys of Quaternary gravel deltas (Singen Basin, SW Germany). Sed Geol 129:281-297

Babek O, Hilscherova K, Nehyba S, Zeman J, Famera M, Francu J, Holoubek I, Machat J, Klanova J (2008) Contamination history of suspended river sediments accumulated in oxbow lakes over the last 25 years. J Soil Sediment 8:165-176

Bano M, Marquis G, Niviere B, Maurin JC, Cushing M (2000) Investigating alluvial and tectonic features with ground-penetrating radar and analyzing diffractions patterns. J Appl Geophys 43:33-41

Bartkowski T (1965) O formach rozcięcia marginalnego i niektórych formach strefy marginalnej na Nizinie Wielkopolskiej (in Polish). Badania Fizjograficzne nad Polską Zachodnią, t. XV: $1-60$

Bersezio R, Giudici M, Mele M (2007) Combining sedimentological and geophysical data for high-resolution 3-D mapping of fluvial architectural elements in the Quaternary Po plain (Italy). Sed Geol 202:230-248

Best J, Woodward J, Ashworth P, Smith GS, Simpson Ch (2006) Bartop hollows: a new element in the architecture of sandy braided rivers. Sed Geol 190:241-255

Blumberg DG, Neta T, Margalit N, Lazar M, Freilikher V (2004) Mapping exposed and buried drainage systems using remote sensing in the Neged Desert, Israel. Geomorphology 61:239-250

Bowling JC, Harry DL, Rodriguez AB, Zheng Ch (2007) Integrated geophysical and geological investigation of a heterogeneous fluvial aquifer in Columbus Mississippi. J Appl Geophys 62: $58-73$

Bridge JS (1993) The interaction between channel geometry, water flow, sediment transport and deposition in braided rivers. In: Best JL, Bristow CS (eds) Braided rivers. Geol Soc London Spec Publ, vol 75, pp 13-71

Bristow CS, Skelly RL, Ethridge FG (1999) Crevasse splays from the rapidly aggrading, sand bed, braided Niobrara River, Nebraska: effect of base-level rise. Sedimentology 46:1029-1047

Choiński A (1992) Katalog jezior Polski, część 3. Pojezierze Wielkopolsko-Kujawskie i jeziora na południe od linii zasięgu zlodowacenia bałtyckiego (in Polish). Fundacja Warta, Poznań

Comas X, Slater L, Reeve A (2004) Geophysical evidence for peat basin morphology and stratigraphic controls on vegetation observed in a Northern Peatland. J Hydrol 295:173-184

Comas X, Slater L, Reeve A (2005) Stratigraphic controls on pool formation in a domed bog inferred from ground penetrating radar (GPR). J Hydrol 315:40-51

Du Y, Xue H-p, Wu Sh-j, Ling F, Xiao F, Wei X-h (2011) Lake area changes in the middle Yangtze region of China over the 20th century. J Environ Manage 92:1248-1255

Dynowska J (1972) Typy reżimów rzecznych w Polsce (in Polish). Zesz Nauk UJ CCXVIII. Prace Geograficzne 28:1-155

Ekes C, Hickin EJ (2001) Ground penetrating radar facies of the paraglacial Cheekye Fan, southwestern British Columbia, Canada. Sed Geol 143:199-217

Froese DG, Smith DG, Clement DT (2005) Characterizing large river history with shallow geophysics: Middle Yukon River, Yukon Territory and Alaska. Geomorphology 67:391-406

Gómez-Ortiz D, Martin-Crespo T, Martin-Velázquez S, MartinezPagán P, Higueraz H, Manzano M (2010) Application of ground penetrating radar (GPR) to delineate clay layers in wetlands. A case study in the Soto Grande and Soto Chico water courses, Doñana (SW Spain). J Appl Geophys 72:107-113

Gourry J-Ch, Vermeersch F, Garcin M, Giot D (2003) Contribution of geophysics to the study of alluvial deposits: a case study in the Val d'Avaray area of the river Loire, France. J Appl Geophys 54: $35-49$

Hickin AS, Kerr B, Barchyn TE, Paulen RC (2009) Groundpenetrating radar and capacitively coupled resistivity to investigate fluvial architecture and grain-size distribution of a gravel floodplain in Northeast British Columbia, Canada. J Sediment Res 79:457-477 
Hilczerówna Z (1967) Dorzecze górnej i środkowej Obry od VI do początków XI wieku (summary in English: The basin of the upper and middle Obra from the VIth to the beginnings of the XIth century). Instytut Historii Kultury Materialnej PAN, Wrocław

Holden J (2004) Hydrological connectivity of soil pipes determined by ground-penetrating radar tracer detection. Earth Surf Proc Land 29:437-442

Huggenberger P, Hoehn E, Beschta R, Woessner W (1998) Abiotic aspects of channels and floodplains in riparian ecology. Freshw Biol 40:407-425

Huisink M (2000) Changing river styles in response to Weichselian climate changes in the Vecht valley, eastern Netherlands. Sed Geol 133:115-134

Jol HM, Smith DG (1995) Ground penetrating radar surveys of peatlands for oilfield pipelines in Canada. J Appl Geophys 34:109-123

Kanbur Z, Gormus M, Kanbur S, Durhan Z (2010) Significance of shallow seismic reflection (SSR) and ground penetrating radar (GPR) profiling on the modern coast line history of the Bedre area, Eğirdir Lake, Isparta, Turkey. J Asian Earth Sci 38:262273

Kehew AE, Kozlowski AL (2007) Tunnel channels of the Saginaw Lobe, Michigan, USA. Special Paper of the Geological Survey of Finland, vol 46, pp 69-78

Kostic B, Aigner T (2007) Sedimentary architecture and 3D groundpenetrating radar analysis of gravelly meandering river deposits (Neckar Valley, SW Germany). Sedimentology 54:789-808

Kostic B, Becht A, Aigner T (2005) 3D sedimentary architecture of a Quaternary gravel delta (SW-Germany): implications for hydrostratigraphy. Sed Geol 181:143-171

Kurnatowski S (1968) Osadnictwo i jego rola w kształtowaniu krajobrazu (summary in English: settlement and its role in the development of landscape). Folia Quat 29:183-197

Leclerc RF, Hickin EJ (1997) The internal structure of scrolled floodplain deposits based on ground penetrating radar, North Thompson river, British Columbia. Geomorphology 21:17-38

Lowry ChS, Fratta D, Anderson MP (2009) Ground penetrating radar and spring formation in a groundwater dominated peat wetland. J Hydrol 373:68-79

Lunt IA, Bridge JS, Tye RS (2004) A quantitative, three-dimensional model of gravelly braided rivers. Sedimentology 51:377-414

MALA (2008) ProEx - Professional Explorer Control Unit. Operating Manual v. 2.0, pp 1-60

Młynarczyk Z, Słowik M (2008a) Temporal variations of suspended sediment concentration during period of high water stages in the lower course of the Obra river (Western Poland). Arch Environ Prot 34:33-49

Młynarczyk Z, Słowik M (2008b) Temporal variation of intensity of bed-load transport rate in the lower course of the Obra river near Miedzyrzecz (western Poland). Quaestiones Geogr 27A:69-86
Mojski E (1976) Mapa geologiczna polski (surface sediments geologic map). Skala 1:200 000. Mapa utworów powierzchniowych mapa podstawowa 1:50 000. Arkusz Świebodzin. PIG, Warszawa

Neal A (2004) Ground penetrating radar and its use in sedimentology: principles, problems and progress. Earth Sci Rev 66:261-330

Pascucci V, Martini P, Endres AL (2009) Facies and groundpenetrating radar characteristics of coarse-grained beach deposits of the uppermost Pleistocene glacial Lake Algonquin, Ontario, Canada. Sedimentology 56:529-545

Rice SP, Church M, Woolridge CL, Hickin EJ (2009) Morphology and evolution of bars of a wandering gravel-bed river; lower Fraser river, British Columbia, Canada. Sedimentology 56:709-736

Sass O, Friedmann A, Haselwanter G, Wetzel K-F (2010) Investigating thickness and internal structure of alpine mires using conventional and geophysical techniques. Catena 80:195-203

Schrott A, Sass O (2008) Application of field geophysics in geomorphology: advances and limitations exemplified by case studies. Geomorphology 93:55-73

Schütze H (1914) Landeskunde der Provinz Posen. Wrocław

Shuman B, Henderson AK, Colman SM, Stone JR, Fritz ShC, Stevens LR, Power MJ, Whitlock C (2009) Holocene lake-level trends in the Rocky Mountains, USA. Quat Sci Rev 28:1861-1879

Skelly RL, Bristow ChS, Ethridge FG (2003) Architecture of channelbelt deposits in an aggrading shallow sandbed braided river: the lower Niobrara river, northeast Nebraska. Sed Geol 158:249-270

Słowik M (2007) Procesy kształtujące koryto rzeczne na przykładzie dolnego odcinka Obry (summary in English: Processes forming river bed: the example of the lower course of the Obra river). Seria Geografia 76, Wydawnictwo Naukowe UAM, Poznań

Słowik M (2009) Wpływ działalności człowieka na zmiany układu koryta rzecznego $\mathrm{w}$ środkowym i dolnym odcinku Obry (in Polish). In: Hildebrandt-Radke I, Jasiewicz J, Lutyńska M (eds) Zapis działalności człowieka w środowisku przyrodniczym. VII Warsztaty Terenowe, 20-22 maja 2009, Kórnik; 133

Słowik M (2011a) Changes of river bed pattern and traces of anthropogenic intervention: the example of using GPR method (the Obra river, western Poland). Appl Geogr 31:784-799

Słowik M (2011b) Changes of river bed pattern of a lowland river: effect of natural processes or anthropogenic intervention? Geogr Ann A. doi:10.1111/j.1468-0459.2011.00432.x (in press)

U.S. Geological survey (2012) Landsat missions. http://landsat.usgs. gov/best_spectral_bands_to_use.php

Van Heteren S, Fitzgerald DM, McKinlay PA, Buynevich PV (1998) Radar facies of paraglacial barrier systems: coastal New England, USA. Sedimentology 45:181-200

Vandenbenghe J, van Overmeeren RA (1999) Ground penetrating radar images of selected fluvial deposits in the Netherlands. Sed Geol 128:245-270

Waters MN, Piehler MF, Rodriguez AB, Smoak JM, Bianchi TS (2009) Shallow lake trophic status linked to late Holocene climate and human impacts. J Paleolimnol 42:51-64 